\title{
Staging and wintering Taiga Bean Geese Anser fabalis fabalis in north-east Scania, south Sweden
}

\author{
Rastande och övervintrande taigasädgäss Anser fabalis fabalis $i$ Nordostskåne
}

\author{
HAKON KAMPE-PERSSON
}

\begin{abstract}
In the municipalities of Bromölla and Kristianstad, south Sweden, monthly counts of Bean Geese have been carried out during October-March/April since November 1976. The seasonal peak count was up to $1987 / 1988$ recorded in March, during the following six seasons in January, and from 1994/1995 onwards in November or December. April numbers decreased from more than 5000 birds in 1977 to hardly any at all from 1997 onwards. Fewer Bean Geese were counted up to the 1986/1987 season than thereafter. In most of the last 25 seasons, the number of Taiga Bean Geese Anser fabalis fabalis in north-east Scania peaked at about $20 \%$ of the total Western Palearc-
\end{abstract}

tic population, with a highest count of 24000 birds in December 1997. Most or all Bean Geese left north-east Scania during severe winters. Checks of staging bean goose flocks and hunting bags showed that, except for Lake Hammarsjön from 2004/2005 onwards and a few flocks in the other areas, the Tundra Bean Goose Anser serrirostris rossicus was quite rare in the region.

Hakon Kampe-Persson, Pulmaņi, Glūdas pagasts, Jelgavas novads, LV-3040, Latvia.

Email: kampepersson@hotmail.com

Received 1 March 2013, Accepted 1 February 2014, Editor: Å. Lindström

\section{Introduction}

The breeding range of the Taiga Bean Goose Anser fabalis fabalis stretches from Scandinavia to the lower Ob region, western Siberia (Alphéraky 1905, Nilsson et al. 1999). It breeds in the forest zone, in areas with a mixture of different types of mire, mire forest, ponds and small lakes. High breeding densities have been found in the aapa mire zone (Pirkola \& Kalinainen 1984).

The majority of all Taiga Been Geese stages in Sweden in late autumn (Nilsson 2013a), and winters in south Sweden and Denmark (Nilsson et al. 1999), with small numbers in Scotland and Norfolk (Mitchell et al. 2010). Staging areas of birds migrating on a route south of the Baltic Sea are less well known (Kampe-Persson 2010a). That part of the population winters in north-east Germany and north-west Poland (Heinicke 2004, Heinicke et al. 2005), with small numbers in the Netherlands and Belgium (Nilsson et al. 1999, Koffijberg et al. 2011). There are also small numbers of Taiga Bean Geese wintering in central Asia (Heinicke 2009).

Taiga Bean Geese use different migration routes to their winter quarters (Söderberg 1917, Jäger- skiöld \& Kolthoff 1926). Large efforts to map these migration routes have been undertaken but little is known of where birds from different parts of the breeding range stage and winter. Birds fitted with GPS tags in Scotland revealed a spring migration route through North Jutland and Oslo to breeding grounds in the Swedish province of Dalarna (http://scotlandsbeangeese.wikispaces.com). The vast majority of birds neck-collared at a moulting site in the southern part of Swedish Lapland were re-sighted staging in both autumn and spring in north-west Jutland and wintering in Norfolk (Parslow-Otsu 1991, Parslow-Otsu \& Kjeldsen 1992). Birds fitted with satellite transmitters during spring staging in northern Sweden were followed to breeding grounds in northernmost Sweden, Finnmark in Norway and Karelia in Russia, as well as to moulting grounds on Novaja Zemlja (Nilsson et al. 2010). Neck-collared individuals from these spring staging areas were in winter re-sighted at the Swedish west coast, in North Jutland and in Scania (Skyllberg et al. 2009a). Birds ringed at moulting sites in north Norway were recovered, most of them hunted, along the west coast of Finland and at haunts in south Sweden and Denmark (Tveit 
1984). Finnish Taiga Bean Geese mainly winter in south Sweden (Nilsson 2011) and to a lesser extent in Denmark, Germany and the Netherlands (Saurola et al. 2013). Recoveries of birds ringed in the Netherlands revealed migration routes to partly northern Fennoscandia and partly the west Siberian lowland (Burgers et al. 1991). Re-sightings of birds neck-collared in Germany indicated that most Taiga Bean Geese wintering in Germany and Poland use a migration route south of the Baltic Sea (Heinicke 2010).

The Taiga Bean Goose is listed as Near Threatened in the Swedish Red List (Tjernberg et al. 2010) and qualifies to be red-listed also internationally. The population wintering in the Western Palearctic declined from 100000 birds in the 1990s to 63000 birds in the season 2008/2009 (Nilsson et al. 1999, Fox et al. 2010). The wintering population in central Asia has been estimated at 2000-5000 birds (Heinicke 2009). Whether the population decline is caused by factors acting during the breeding (Mellquist \& von Bothmer 1982, Filchagov et al. 1985, Kampe-Persson et al. 2005) or the non-breeding season (Huyskens 1999) is not known. Also unknown is when the decline started and whether all parts of the breeding range have been affected. The Swedish breeding range, for instance, was markedly reduced already between 1922 and 1969 (Mellquist \& von Bothmer 1982).

The lack of explanation to the recorded population declines is due to difficulties to study this taxon. Taiga Bean Geese breed in remote areas and are experts of concealment. They can be hard to find also during the non-breeding season (Parslow-Otsu \& Kjeldsen 1992, Kampe-Persson 2010a, b). A factor that has caused large problems for more than a century is misidentification. During the non-breeding season, the Taiga Bean Goose regularly occurs together with other bean goose taxa, of which the Tundra Bean Goose Anser serrirostris rossicus is the most numerous. In this contribution, Taiga Bean Goose and Tundra Bean Goose were treated as species (Naumann 1842, Van Impe 1980a, b, Sangster \& Oreel 1996, Sangster et al. 1999, 2003, Banks et al. 2007, Mitchell \& Vinicombe 2012). As the taxonomy differs among countries, the Taiga Bean Goose and the Tundra Bean Goose are as a rule referred to as fabalis and rossicus, respectively. Also Middendorff's Bean Goose Anser (fabalis) middendorffii and the Thick-billed Bean Goose Anser serrirostris serrirostris have been reported from north-west Europe (van den Bergh 2003b, 2004).

Based on material from Mecklenburg and Brandenburg it was stated that the majority of all
Bean Geese were made up of hybrids between $f a$ balis and rossicus (Litzbarski 1974, Cramp 1977, Ogilvie 1978, Klafs \& Stübs 1979, Owen 1980, Rutschke 1983, 1987, Liebherr \& Rutschke 1993). This conclusion was the result of a typological way of looking at the birds; all individuals that differed from the "type individual" were regarded as belonging to a mixed population. In reality, there is large individual variation, especially in size, shape and colouration of the bill, in both fabalis and rossicus (see e.g. Liebherr \& Rutschke 1993). Despite the fact that fabalis and rossicus often occur in mixed flocks, mixed pairs of these taxa are rare (Kampe-Persson \& Lerner 2007, Leo van den Bergh in litt., Thomas Heinicke pers. comm.) and hybrids of supposedly wild origin are limited to one bird observed in north-east Scania (Kampe-Persson \& Lerner 2007, and unpubl.). Due to misidentification there is a lack of data about the number of staging and wintering Taiga Bean Geese in Germany before the early 1990s. In Sweden, counters have usually not separated Taiga and Tundra Bean Geese but reported them all as "sädgäss" ("bean geese"). For that reason, Bean Goose in Swedish reports (Nilsson 2000) has been denoted as "a fabalis population mixed with small numbers of rossicus and a few occasional middendorfi and serrirostris." Up to about ten years ago the total number of staging Tundra Bean Geese in Sweden only occasionally exceeded 1000 individuals but the taxon has become more numerous since then (Persson 1990, 1997b, Kampe-Persson 2011, Heinicke \& de Jong 2013).

Many changes in the non-breeding distribution of geese have been described in the last decades. One major pattern is referred to as "short-stopping". This term is used when southerly areas are deserted by birds as conditions closer to the breeding grounds become favourable. This phenomenon has been reported for several goose species (Mathiasson 1963, Kear 1965, Reeves et al. 1968, Dzubin et al. 1975, Owen 1980, Persson \& Urdiales 1995, Kampe-Persson 2002). The changes in bean goose occurrence in north-east Scania described in this contribution will partly be interpreted as "shortstopping".

Long-term monitoring in a region of importance during the non-breeding season can give valuable information for the conservation of a species. The more if the counts have covered the entire nonbreeding season and the actual region is situated at a crucial part of the species' non-breeding range. The aim of this contribution was to document the monthly counts of Bean Geese undertaken in 
north-east Scania from November 1976 to December 2013 and to put these counts, as well as counts carried out during the years 1947-1976, into a historical, ecological and international context.

\section{Study area}

The study area comprises the two municipalities Bromölla and Kristianstad, and a small area in the municipalities Hässleholm and Östra Göinge as well, north-east Scania, south Sweden (Figure 1). The main soil type is sand, the area is situated south of the January $-1.0^{\circ} \mathrm{C}$ isotherm and the annual precipitation ranges from $500 \mathrm{~mm}$ at the coast to $600 \mathrm{~mm}$ inland, of which $10-20 \%$ comes as snow (Germundsson \& Schlyter 1999). One third of the total land area is used for agriculture. The main crops are (percentage of total cultivated area in 2012$)$ : cereals $(36 \%)$, grasses $(29 \%)$, potatoes $(9 \%)$, sugar beet $(7 \%)$, vegetables $(6 \%)$, oilseed rape $(4 \%)$ and maize (2\%) (http://statistik.sjv.se). All fields are situated within normal flight distances of a night roost (Persson 1989). The shallow coast between Landön and Tosteberga, River Helgeå, and the Lakes Ivösjön, Oppmannasjön, Råbelövsjön, Gummastorpasjön, Araslövsjön, Hammarsjön, Pulken and Yngsjösjön have been used for roosting (Mathiasson 1963, Swegen 1963, Hakon KampePersson pers. obs.). The coastal roost was, at least earlier, also used by Taiga Been Geese feeding at Vesan in the westernmost part of the province of Blekinge (Nilsson \& Persson 1984). River Helgeå, the largest river in the study area, flows or flowed through Lakes Gummastorpasjön, Araslövsjön, Hammarsjön, Pulken, Yngsjösjön and Egeside.

Also other geese than the bean geese spend the non-breeding season in north-east Scania (KampePersson et al. 2007, www.spoven.com). Most counts of Canada Geese Branta canadensis in the months October-March during the period 1976/19772013/- ranged between 1500 and 10000 birds but numbers were higher from the 1999/2000 season onwards than before. The Greylag Goose Anser anser occurred in quite low numbers up to 1990/1991. Numbers increased during the 1990s and from 2001 counts often exceeded 10000 in September and October, from 2005 also in November. The occurrence during the winter months fluctuated greatly depending on the severity of the winter, with a maximum count of 7000 birds in February 2008. Since 2003, about 6000 birds were often counted in March. In 1993, the number of Barnacle Geese Branta leucopsis in October and November started to increase. From 2000 onwards, numbers counted in October and November often exceeded 5000 birds, increasing to more than 26000 in November 2013. Occasionally, up to 7000 Barnacle Geese were found in September and up to 12000 in December. The White-fronted Goose Anser albifrons has been more numerous from 1995 onwards than previously but numbers have rarely exceeded 1000 birds.

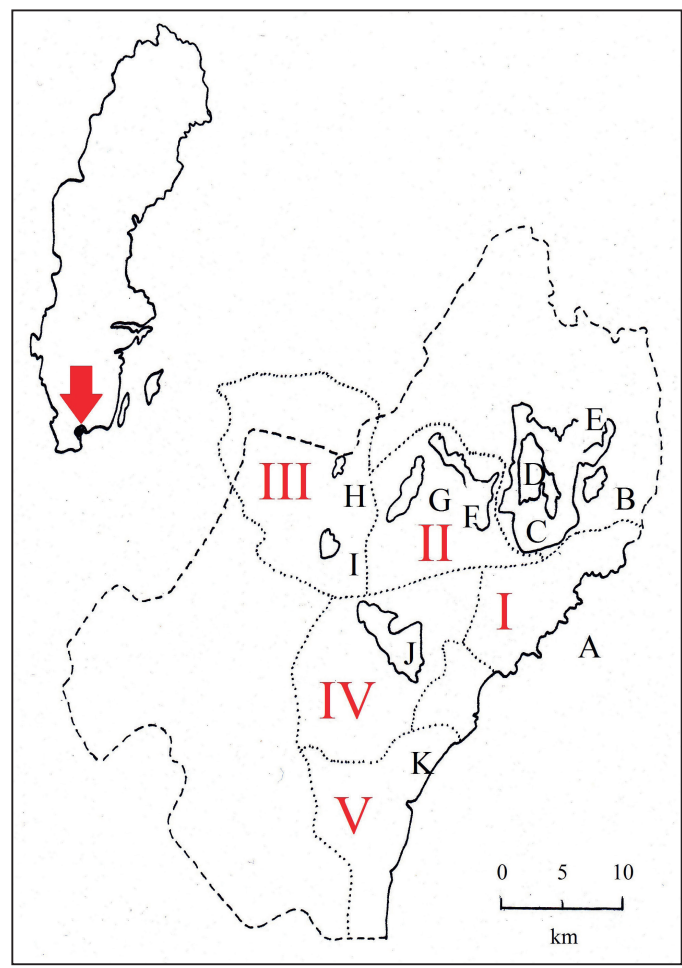

Figure 1. Map of the study area. Depicted are the land border of the municipalities Bromölla and Kristianstad (broken line), shorelines (unbroken line) and borders of the five main census areas (stippled line); I. Trolle-Ljungby, II. Oppmannasjön + Råbelövsjön, III. Araslövsjön + Gummastorpasjön, IV. Hammarsjön and V. Egeside. A = coastal roost between Landön and Tosteberga, B = Lake Levrasjön, C = Lake Ivösjön, D = Ivö, E = Näsum, F = Lake Oppmannasjön, G = Lake Råbelövsjön, H = Lake Gummastorpasjön, I = Lake Araslövsjön, $\mathrm{J}=$ Lake Hammarsjön and $\mathrm{K}=$ Egeside.

Karta över undersökningsområdet. Markerat är landgränsen för kommunerna Bromölla och Kristianstad (streckad linje), strandlinjer (heldragen linje) samt gränserna för de fem huvudsakliga inventeringssområdena (prickad linje); I. Trolle-Ljungby, II. Oppmannasjön + Råbelövsjön, III. Araslövsjön + Gummastorpasjön, IV. Hammarsjön och V. Egeside. $A=$ nattplats längs kusten mellan Landön och Tosteberga, $B=$ Levrasjön, $C=I$ vösjön, $D=I$ vö, $E=$ Näsum, $F$ = Oppmannasjön, $G=$ Råbelövsjön, $H=$ Gummastorpasjön, $I=$ Araslövsjön, $J=$ Hammarsjön och $K=$ Egeside . 


\section{Material and methods}

Goose counts 1976/1977-2013/-

The part of the study area used by geese during the non-breeding season was divided into five census areas (Neideman \& Svensson 1976, Figure 1): TrolleLjungby, Oppmannasjön + Råbelövsjön, Araslövsjön + Gummastorpasjön, Hammarsjön and Egeside. Later, two sites at Lake Ivösjön were added: Näsum from October 2003 and Ivö from December 2006. At Lake Levrasjön geese were counted within the framework of mid-monthly waterfowl counts but no Taiga Bean Geese were encountered (Persson \& Persson 1992, and unpubl.). The division into census areas was based upon well-defined borders, usually larger roads. By that, doubts were avoided regarding who should count the geese in each flock.

With some exceptions given below, counts were undertaken by members of the local bird-watching society, Nordöstra Skånes Fågelklubb, every month during the period October-April. In addition, September counts were carried out in 1977 and from 1993 onwards. Only three complete counts were carried out in 1976/1977 and 1978/1979, but another three counts were undertaken in some of the census areas during the last-mentioned season. Due to blizzards with snowed-up roads, only some of the census areas could be checked in February 1978 and no area at all in December 2012. Due to advancement of the pre-nuptial migration, and therefore no geese present, there have been no counts in April since 2004.

The counts were undertaken Saturday morning during the week-end closest to the 15th. The majority of all geese were counted more or less simultaneously while seeking food in the fields. All individuals of all goose species were counted. Taiga Bean Geese and Tundra Bean Geese were not differentiated but reported as Bean Geese.

The counted numbers should be regarded as minimum numbers, especially during the first seasons, before the observers learned the counting technique. Problems during the counts were caused by rain, wind (January 2007 and March 2007), mist (February 2005, November 2007 and December 2007) and hunting (October 2003, November 2006 and November 2009). Due to these problems, some geese were not found by the observers, while others were reported as unidentified. Up to 90 unidentified geese were noted on 19 occasions, 17 of these before the 1990/1991 season, while more than 100 unidentified were noted on five occasions; 336 in October 1977, 536 in October 1984, 516 in December 1986, 303 in January 1999 and 1100 in February 2004 (Kampe-Persson 2007).
Proportions of Taiga Bean Goose and Tundra Bean Goose

To obtain estimates of the proportion of Taiga Bean Geese among the staging and wintering bean geese, three sets of data were used: field checks in 1976-2013 by the author, Georges Huyskens, Leo van den Bergh, Thomas Heinicke, Frank Abrahamson, Greger Flyckt and Sven Birkedal, checks of hunting bags at Trolle-Ljungby Manor, and observations of staging flocks of Tundra Bean Geese numbering at least 50 birds. Huyskens, van den Bergh, Heinicke and Abrahamson checked the bean geese in the five main census areas, Flyckt at Egeside, Birkedal at Trolle-Ljungby, and the author mainly at Trolle-Ljungby and Oppmannasjön. No checks were undertaken at Hammarsjön and Egeside during the seasons 2004/2005-2008/2009 and no checks at all at Ivösjön.

\section{Results}

Goose counts 1976/1977-2013/-

Both temporal and numerical changes took place in north-east Scania during the period 1976/19772013/- (Table 1). Numbers of Bean Geese in April decreased from more than 5000 birds at the first count to hardly any at all from 1997 onwards. A similar change, though on a smaller scale, might have taken place in the autumn, because 389 birds were counted in September 1977 (Svensson 1977), the only September count undertaken before 1993. The seasonal peak count was up to the 1987/1988 season recorded in March, during the following six seasons in January and from the 1994/1995 season onwards in November or December. In general, fewer Bean Geese were counted up to the $1986 / 1987$ season than thereafter. Count figures exceeding 22000 birds were recorded five times during the period 1991/1992-2004/2005 and the highest count was of 24064 birds in December 1997. Most or all Bean Geese left north-east Scania during severe winters.

Except for Egeside and Ivösjön the different census areas showed about the same temporal and numerical changes as the entire area (Appedix 1-6). In general, Trolle-Ljungby was the area housing most staging and wintering Bean Geese, the seasonal peak count often exceeding 10000 birds, reaching 15802 in November 2003 (Appendix 1). Oppmannasjön + Råbelövsjön showed the largest among-year variation in both occurrence pattern and numbers (Appendix 2). In most seasons during 
Table 1. Number of Bean Geese recorded at mid-monthly counts in the municipalities of Bromölla and Kristianstad, 1976/1977-2013/-. A bar (-) indicates that no complete count was carried out that month.

Antalet sädgäss inräknade vid mittmånads-inventeringar i Bromölla och Kristianstad kommuner säsongerna 1976/1977-2013/-. Minustecken (-) anger att ingen komplett inventering genomfördes den månaden.

\begin{tabular}{|c|c|c|c|c|c|c|c|}
\hline & October & November & December & January & February & March & April \\
\hline $76 / 77$ & - & 3567 & - & 609 & - & 5807 & - \\
\hline $77 / 78$ & 1855 & 5500 & 4981 & 7919 & - & 11140 & 5641 \\
\hline 78/79 & 1906 & - & - & 728 & - & 6617 & - \\
\hline $79 / 80$ & 825 & 5061 & 3628 & 2036 & 1 & 5244 & - \\
\hline $80 / 81$ & 956 & 5300 & 2075 & 3822 & 5047 & 5374 & 3487 \\
\hline $81 / 82$ & 2036 & 4781 & 1925 & 0 & 69 & 17345 & 6448 \\
\hline $82 / 83$ & 1016 & 4943 & 8200 & 6747 & 1648 & 13462 & 3517 \\
\hline $83 / 84$ & 770 & 5434 & 2032 & 9407 & 4901 & 10958 & 4831 \\
\hline $84 / 85$ & 1909 & 3881 & 11849 & 1461 & 887 & 8280 & 5369 \\
\hline $85 / 86$ & 295 & 5118 & 3361 & 269 & 633 & 6761 & 4238 \\
\hline $86 / 87$ & 674 & 3358 & 7975 & 0 & 186 & 1442 & 1761 \\
\hline $87 / 88$ & 247 & 3013 & 12763 & 8288 & 14344 & 17767 & 1314 \\
\hline $88 / 89$ & 31 & 7110 & 12021 & 19960 & 9694 & 1379 & 839 \\
\hline $89 / 90$ & 372 & 1977 & 7804 & 16359 & 13107 & 628 & 480 \\
\hline 90/91 & 342 & 10581 & 17703 & 16913 & 4968 & 1611 & 275 \\
\hline 91/92 & 5 & 10397 & 13644 & 23874 & 16564 & 836 & 507 \\
\hline $92 / 93$ & 762 & 15310 & 12319 & 16099 & 15385 & 4694 & 192 \\
\hline 93/94 & 786 & 10181 & 9456 & 14213 & 8802 & 7115 & 377 \\
\hline 94/95 & 810 & 17518 & 18366 & 17222 & 12727 & 695 & 101 \\
\hline 95/96 & 248 & 9415 & 12636 & 523 & 7630 & 13541 & 224 \\
\hline 96/97 & 201 & 14510 & 18693 & 3106 & 8460 & 515 & 59 \\
\hline 97/98 & 930 & 19933 & 24064 & 16390 & 8627 & 1766 & 7 \\
\hline 98/99 & 8 & 16086 & 13635 & 10171 & 6034 & 2081 & 0 \\
\hline $99 / 00$ & 2300 & 13201 & 16810 & 13918 & 6320 & 389 & 1 \\
\hline 00/01 & 40 & 4186 & 11178 & 15637 & 13657 & 578 & 0 \\
\hline 01/02 & 35 & 18223 & 14512 & 3762 & 11234 & 53 & 0 \\
\hline $02 / 03$ & 711 & 20793 & 22274 & 8387 & 7598 & 333 & 64 \\
\hline 03/04 & 3 & 23752 & 15099 & 10326 & 6813 & 4572 & - \\
\hline $04 / 05$ & 243 & 23381 & 14818 & 10256 & 9685 & 8582 & - \\
\hline $05 / 06$ & 217 & 3753 & 17633 & 7765 & 8540 & 4127 & - \\
\hline 06/07 & 866 & 18329 & 13835 & 8802 & 9867 & 90 & - \\
\hline 07/08 & 511 & 16156 & 15862 & 14846 & 8831 & 138 & - \\
\hline 08/09 & 0 & 6066 & 12034 & 11715 & 11483 & 286 & - \\
\hline $09 / 10$ & 441 & 6829 & 15173 & 7291 & 4162 & 9380 & - \\
\hline 10/11 & 2446 & 12636 & 5631 & 533 & 2247 & 8753 & - \\
\hline $11 / 12$ & 1372 & 13143 & 12999 & 9980 & 5176 & 153 & - \\
\hline $12 / 13$ & 20 & 4593 & - & 7387 & 7278 & 17159 & - \\
\hline $13 / 14$ & 122 & 3756 & 19402 & - & - & - & - \\
\hline
\end{tabular}

the entire survey period, the seasonal peak count was in the range 2000-2500 birds at Araslövsjön + Gummastorpasjön (Appendix 3) and around 5000 birds at Hammarsjön (Appendix 4). Egeside, on the other hand, was a typical wintering and spring staging area with few Bean Geese in autumn, often no birds at all in October (Appendix 5). A similar timing of the occurrence was reported for the Egeside area in the period 1970-1976 (Månsson 1977). The seasonal peak count usually fell in the range 2500-4000 birds during the period 1987/1988-
2005/2006, lower before and after that period. The Bean Geese at Ivösjön were counted too few seasons to discern any patterns (Appendix 6).

\section{Proportions of Taiga Bean Goose and Tundra Bean Goose}

Field checks of 1000 or more bean geese were realised in a total of 45 months during the period 1976/1977-2013/- (Table 2). The proportion of Taiga Bean Geese during these checks was $100 \%$ 
Table 2. Percentage of the staging and wintering bean geese in the municipalities of Bromölla and Kristianstad that was made up of Taiga Bean Geese Anser fabalis fabalis, 1976/1977-2013/-. No checks were undertaken in the census areas Hammarsjön and Egeside during the seasons 2004/2005-2008/2009. The census area Hammarsjön was excluded from the 2009/2010 season onwards. Data are given for months when at least 1000 bean geese were checked (sample sizes in brackets). For the remaining months, a bar indicates that no complete midmonthly count was carried out or that fewer than 1000 bean geese were found. Sources other than the author: October 1983 and November 1984 (Huyskens 1986); December 1986, October 1993, October 1994 and October 2003 (Leo van den Bergh in litt.); February 2012, March 2013 and November 2013 (reports on http://svalan. artdata.slu.se/birds); December 2013 (Evert Valfridsson in litt., reports on http://svalan.artdata.slu.se/birds).

Procentandelen av de rastande och övervintrande sädgässen i Bromölla och Kristianstad kommuner som utgjordes av taigasädgäss Anser fabalis fabalis säsongerna 1976/1977-2013/-. Inga kontroller företogs inom räkningsområdena Hammarsjön och Egeside under säsongerna 2004/2005-2008/2009. Räkningsområdet Hammarsjön exkluderades från och med säsongen 2009/2010. Resultat ges för de månader då mer än 1000 sädgäss kontrollerades (antalet kontrollerade sädgäss anges inom parentes). För övriga månader anger ett minustecken att ingen komplett mittmånadsinventering genomfördes eller att färre än 1000 sädgäss hittades. Källor andra än författaren: oktober 1983 och november 1984 (Huyskens 1986); december 1986, oktober 1993, oktober 1994 och oktober 2003 (Leo van den Bergh i brev); februari 2012, mars 2013 och november 2013 (rapporter på http://svalan.artdata.slu.se/birds); december 2013 (Evert Valfridsson i brev, rapporter på http://svalan.artdata. slu.se/birds).

\begin{tabular}{|c|c|c|c|c|c|c|}
\hline & October & November & December & January & February & March \\
\hline $76 / 77$ & 99.5 (1 256) & 99.7 (2 010) & - & - & - & \\
\hline $77 / 78$ & $100(1500)$ & $100(6500)$ & & & - & $100(1909)$ \\
\hline 78/79 & & - & $100(2618)$ & - & - & \\
\hline $79 / 80$ & - & & & & - & \\
\hline $80 / 81$ & - & $100(2230)$ & $100(1090)$ & & & \\
\hline $81 / 82$ & & & & - & - & \\
\hline $82 / 83$ & & & $100(2500)$ & $100(1750)$ & $100\left(\begin{array}{ll}1 & 364\end{array}\right)$ & \\
\hline $83 / 84$ & $100(2176)$ & $100(4310)$ & $100(2501)$ & $100(2550)$ & & $100(3875)$ \\
\hline $84 / 85$ & & $100(3000)$ & $100(1730)$ & $100(2750)$ & $100\left(\begin{array}{ll}1 & 050\end{array}\right)$ & \\
\hline $85 / 86$ & - & & & - & - & \\
\hline $86 / 87$ & $100\left(\begin{array}{lll}1 & 011\end{array}\right)$ & $100(2200)$ & $100(4$ 417) & - & - & \\
\hline $87 / 88$ & - & & & & & \\
\hline $88 / 89$ & - & & & & & \\
\hline $89 / 90$ & - & & & & & - \\
\hline 90/91 & - & & & & & \\
\hline 91/92 & - & & & & & - \\
\hline $92 / 93$ & $100\left(\begin{array}{ll}1 & 050\end{array}\right)$ & & & & & \\
\hline 93/94 & $99.9(8007)$ & & & & & \\
\hline $94 / 95$ & $96.8(3077)$ & & & & & - \\
\hline 95/96 & - & & & - & & \\
\hline 96/97 & $99.4(3520)$ & $99.9(12715)$ & & & & - \\
\hline 97/98 & - & & & & & \\
\hline 98/99 & - & $99.8\left(\begin{array}{l}10 \\
10\end{array}\right)$ & & & & \\
\hline $99 / 00$ & $99.8(6410)$ & & 99.8 (6 813) & & & - \\
\hline 00/01 & - & & & & & - \\
\hline $01 / 02$ & - & & & & & - \\
\hline $02 / 03$ & - & & & & & - \\
\hline 03/04 & $98.1(2818)$ & & & & & \\
\hline $04 / 05$ & - & & $100(3498)$ & & & \\
\hline 05/06 & - & & & & & \\
\hline 06/07 & - & & $99.9(7800)$ & & & - \\
\hline $07 / 08$ & - & & $99.9(7500)$ & & & - \\
\hline 08/09 & - & & & & & - \\
\hline $09 / 10$ & - & & & $99.9(4884)$ & & \\
\hline $10 / 11$ & & 98.8 (6 201) & & & & \\
\hline $11 / 12$ & & $98.8(6578)$ & & $100(7970)$ & $99.4(2424)$ & \\
\hline $12 / 13$ & - & $99.6(2489)$ & - & $100(1626)$ & & $100(4$ 196) \\
\hline $13 / 14$ & - & $99.9(4146)$ & $99.1(6213)$ & & & \\
\hline
\end{tabular}


Table 3. Staging flocks of Tundra Bean Goose Anser serrirostris rossicus numbering at least 50 individuals in the municipalities of Bromölla and Kristianstad, up to 2013.

Rastande flockar av tundrasädgås Anser serrirostris rossicus i Bromölla och Kristianstad kommuner fram till och med 2013 som uppgått till minst 50 individ.

\begin{tabular}{|c|c|c|c|}
\hline & No. Antal & Site Lokal & Source/observer Källa/observatör \\
\hline 14 April 1974 & 60 & Tosteberga & Hakon Kampe-Persson \\
\hline 14 February 1975 & $>50$ & Trolle-Ljungby & Hakon Kampe-Persson \\
\hline 18 October 1975 & 250 & Trolle-Ljungby & Persson 1990 \\
\hline 2 November 1975 & $100-300$ & Trolle-Ljungby & Hakon Kampe-Persson \\
\hline 27 October 1994 & 85 & Trolle-Ljungby & Leo van den Bergh in litt. \\
\hline 11 January 2003 & 95 & Hovby & Flyckt et al. 2004 \\
\hline 9 March 2003 & 580 & Vanneberga & Flyckt et al. 2004 \\
\hline 29 February 2004 & 70 & Yngsjö & Bernsmo et al. 2005 \\
\hline 13 March 2004 & 120 & Trolle-Ljungby & Bernsmo et al. 2005 \\
\hline 2-11 February 2006 & 65 & Trolle-Ljungby & Bernsmo et al. 2007 \\
\hline 5 November 2006 & 200 & Tosteberga & Bernsmo et al. 2007 \\
\hline 3-4 February 2007 & 50 & Yngsjö & Bernsmo et al. 2008 \\
\hline 6 December 2009 & 90 & Vanneberga & Karlsson et al. 2010 \\
\hline 4 January 2010 & 55 & Tosteberga & Bernsmo et al. 2011 \\
\hline 12 November 2010 & 72 & Östra Ljungby & Hakon Kampe-Persson \\
\hline Mid November 2010 & 5042 & Hammarsjön & Thomas Heinicke \\
\hline 12 February 2011 & 85 & Hovby & Bernsmo et al. 2012 \\
\hline 12 February 2011 & 50 & Hovby & Bernsmo et al. 2012 \\
\hline 12 November 2011 & 54 & Hovby & Frank Abrahamson \\
\hline 14 January 2012 & 350 & Hovby & Frank Abrahamson \\
\hline 14 January 2012 & 1100 & Norra Åsum & Frank Abrahamson \\
\hline Mid January 2012 & 4988 & Hammarsjön & Thomas Heinicke \\
\hline 4 February 2012 & 235 & Gärds Köpinge & Frank Abrahamson \\
\hline 2 March 2013 & 210 & Hovby & Frank Abrahamson \\
\hline 2 March 2013 & 256 & Svaneholm & Frank Abrahamson \\
\hline 2 March 2013 & 450 & Mosslunda & Frank Abrahamson \\
\hline 9 March 2013 & 71 & Hovby & Frank Abrahamson \\
\hline 9 March 2013 & 111 & Gärds Köpinge & Frank Abrahamson \\
\hline 16 March 2013 & 309 & Gärds Köpinge & Frank Abrahamson \\
\hline 23 March 2013 & 420 & Horna & Frank Abrahamson \\
\hline 23 March 2013 & 200 & Hovby & Frank Abrahamson \\
\hline 23 March 2013 & 1900 & Hovby & Frank Abrahamson \\
\hline 17 November 2013 & 300 & Hovby ängar & Frank Abrahamson \\
\hline 23 November 2013 & 90 & Gärds Köpinge & Greger Flyckt \\
\hline 30 November 2013 & 620 & Hovby & Frank Abrahamson \\
\hline 8 December 2013 & 100 & Yngsjö & Greger Flyckt \\
\hline 8 December 2013 & 460 & Egeside & Greger Flyckt \\
\hline 15 December 2013 & 4489 & Vittskövle & Frank Abrahamson \\
\hline 22 December 2013 & 1100 & Vittskövle & Greger Flyckt \\
\hline
\end{tabular}

27 times, 99.1-99.9\% 14 times and $96.8-98.8 \%$ four times. Of bean geese hunted and taxonomically checked at Trolle-Ljungby Manor during the years $1976-2012,99.9 \%(\mathrm{~N}=2043)$ were Taiga Bean Geese. Flocks numbering 50 or more Tundra Bean Geese were reported 39 times in the study area up to 2013 (Table 3). All but five of these observations were made during the years 2003-2013. Flocks numbering more than 1000 Tundra Bean Geese were only recorded in the census area Hammarsjön during the last four seasons of the survey period. In the fields around Lake Hammarsjön, up to 5000 Tundra Bean Geese but very few Taiga Bean Geese were found in the seasons 2010/2011-2013/- (Table 3, reports on http://svalan.artdata.slu.se/birds). In meadows along the shores of this lake however, especially in Rinkaby ängar and Hovby ängar, flocks of up to 415 Taiga Bean Geese were recorded between mid-January and mid-March in the seasons 2010/2011-2012/2013 (reports on http://svalan.artdata.slu.se/birds). 


\section{Discussion}

Both Taiga and Tundra Bean Geese occur in northeast Scania but undoubtedly, the vast majority of the birds counted were Taiga Bean Geese. However, to be able to interpret the overall picture, I start by discussing the much rarer Tundra Bean Goose.

\section{Tundra Bean Goose}

During the last decade, increasing numbers of Tundra Bean Geese have started to winter in Denmark (Pihl \& Vikstrøm 2006, Stefan Pihl unpubl.) and at Lake Hammarsjön (Heinicke \& de Jong 2013).
As no field checks were carried out at Lake Hammarsjön in the seasons 2004/2005-2008/2009, it is not known when the Tundra Bean Goose started to use that area for staging and wintering. The fact that 4988 birds were counted in January 2012 compared to none a year earlier should not be regarded as the start of wintering however, as it merely reflects the severity of the winter. Few Tundra Bean Geese remain in north-east Scania in severe winters (Heinicke \& de Jong 2013). The Tundra Bean Geese found at Lake Hammarsjön very likely originated from the westernmost part of the breeding range (van den Bergh 1999, Aarvak \& Øien 2009). Birds neck-collared in northernmost Norway from 2003

Table 4. Number of Bean Geese recorded during counts in the municipalities of Bromölla and Kristianstad before the 1976/1977 season. Besides five complete counts, results are given for one count covering two areas and 23 single area counts. Count data provided by the author and Huyskens (1986) refer to Taiga Bean Geese. Antalet sädgäss inräknade vid inventeringar i Bromölla och Kristianstad kommuner före säsongen 1976/1977. Utöver fem kompletta inventeringar ges resultat från en inventaring omfattade två områden och 23 inventeringar omfattande vardera ett område. Inventeringssiffror givna av författaren och Huyskens (1986) avser taigasädgäss.

\begin{tabular}{lrll}
\hline & No. & Area(s) & Source/observer \\
& Antal & Omräde(n) & Källa/observatör \\
\hline 18 May 1950 & 300 & Araslövsjön & Mathiasson 1963 \\
22 January 1951 & 210 & Hammarsjön & Mathiasson 1963 \\
25 May 1952 & 300 & Araslövsjön & Mathiasson 1963 \\
4 December 1955 & 1000 & Araslövsjön & Mathiasson 1963 \\
5 May 1956 & $20-25$ & Hammarsjön & Mathiasson 1963 \\
9-15 November 1956 & 2000 & Araslövsjön + Hammarsjön & Mathiasson 1963 \\
2 May 1958 & 100 & Hammarsjön & Mathiasson 1963 \\
17 November 1958 & 3000 & Araslövsjön & Mathiasson 1963 \\
1 December 1958 & 1000 & Hammarsjön & Mathiasson 1963 \\
1 March 1959 & 10000 & North-east Scania & Mathiasson 1963 \\
7-8 March 1959 & 3855 & North-east Scania & Mathiasson 1963 \\
5 April 1959 & 945 & North-east Scania & Mathiasson 1963 \\
10 October 1959 & 3000 & Hammarsjön & Mathiasson 1963 \\
30 October 1960 & $>1920$ & Araslövsjön & Jensen et al. 1962 \\
30 October 1960 & 630 & Hammarsjön & Jensen et al. 1962 \\
5 March 1961 & 3000 & Egeside & Swegen 1963 \\
27 October 1973 & 2000 & Trolle-Ljungby & Hakon Kampe-Persson \\
17 November 1973 & 2000 & Trolle-Ljungby & Hakon Kampe-Persson \\
16 February 1974 & 1000 & Trolle-Ljungby & Hakon Kampe-Persson \\
17-19 October 1974 & 800 & North-east Scania & Huyskens 1986 \\
2-3 November 1974 & 450 & Trolle-Ljungby & Hakon Kampe-Persson \\
29-31 December 1974 & 1500 & Trolle-Ljungby & Hakon Kampe-Persson \\
14 February 1975 & 150 & Trolle-Ljungby & Hakon Kampe-Persson \\
12 April 1975 & 575 & Trolle-Ljungby & Hakon Kampe-Persson \\
26 April 1975 & 200 & Trolle-Ljungby & Hakon Kampe-Persson \\
9 November 1975 & 2488 & Trolle-Ljungby & Hakon Kampe-Persson \\
11-14 November 1975 & 4500 & North-east Scania & Huyskens 1986 \\
2 January 1976 & $>2935$ & Trolle-Ljungby & Hakon Kampe-Persson \\
8-25 January 1976 & 1505 & Trolle-Ljungby & Hakon Kampe-Persson \\
8 February 1976 & 1664 & Trolle-Ljungby & Hakon Kampe-Persson \\
\hline & & &
\end{tabular}


onwards have in late autumn and winter mainly been reported from north-east Scania (de Jong et al. 2013). A migration route from northern Fennoscandia through staging areas in north-east Scania to winter quarters in east Germany was indicated in an earlier neck-collaring project (Persson 1997a). Wintering was reported from the Trolle-Ljungby area in the winter 1974/1975 (Persson 1995). The 95 birds observed at Hovby in January 2003 (Table 4) were maybe also wintering.

The establishment of the Tundra Bean Goose as a staging and wintering bird at Lake Hammarsjön shows that areas situated close to each other can develop very differently. Lake Hammarsjön was, in fact, one of a few goose areas in Scania that were not regularly checked for the occurrence of Tundra Bean Geese during the years of establishment (Kampe-Persson 2011, this study). This calls upon awareness of patchy distributions when mapping goose areas (Kampe-Persson 2013b).

\section{Short-stopping}

To follow the short-stopping process at a locality is like viewing the entire flyway during a season. From the north to the south you find in the ideal case a sequence of areas used in different ways: not at all, for staging only, for both staging and wintering, only for wintering, for wintering but in declining numbers and only in the past. Data from Lake Hammarsjön shows an almost complete cycle, as that area was not used by Taiga Bean Geese before 1947 (Nordquist 1947a) and only by low numbers during late winter/early spring nowadays (this study).

A northward shift in the distribution during the non-breeding season has been recorded in the Taiga Bean Goose since the mid $20^{\text {th }}$ century (Mathiasson 1963, Nilsson 2013a). The proportion of the total number of Bean Geese counted in October that was found north of Scania increased from 14\% in 1960 (Mathiasson 1963) to $100 \%$ in 2012 (Nilsson 2013b). During the same period of time, the area holding the largest number of birds in October shifted northwards, first from south-west Scania to Lake Tåkern (50 000 birds in 1988) and then to the province of Närke (35 000 birds in 2001) (Nilsson 2013a). About 1500-3000 birds wintered in southwest Scania and none in the rest of the country during the years 1947-1960 (Mathiasson 1963). Later, the wintering area was extended to include also north-east Scania but the species is only sometimes found north of Scania in January (Nilsson 2013a). Few spring counts are available. The centre of dis- tribution in March was south-west Scania during counts in 1977-1980 (Nilsson \& Persson 1984) but the province of Uppland in 2007 (Skyllberg \& Tjernberg 2008). At Umeå, the peak count was about 3-4 weeks earlier in the springs 2003-2008 (Skyllberg et al. 2009b) compared to in 1977-1980 (Nilsson \& Persson 1984).

The occurrence of Taiga Bean Geese in northeast Scania since the mid 1940s gives an excellent example of short-stopping as it covers also the phase before the birds started to winter. In the 1950 s, this region was only used for staging in autumn and spring of birds that wintered in southwest Scania, Denmark, Germany and Netherlands (Nilsson 1984). Large acreages of autumn-sown crops and milder winters gradually made it possible for the geese to winter in north-east Scania. However, the severity of the winter, primarily the thickness of the snow-cover on the feeding grounds, determined how many geese that actually could remain the entire winter. Often, heavy snowfall forced the geese to move southwards/ south-westwards for shorter or longer periods of time. At the same time as conditions for wintering improved in north-east Scania conditions for staging, especially in spring, improved further north. To be able to match the phenology of their main food plants along their migratory pathways (Drent 1996, Drent et al. 2006, Nilsson 2006, Tombre et al. 2008) the geese started to initiate their pre-nuptial migration from this region earlier and earlier. The last phase in the on-going process would be for the geese to choose winter quarters closer to their breeding grounds. Lower numbers of Taiga Bean Geese in north-east Scania during the last decade compared to the decade before might be a step to complete disappearance from the region. However, lower numbers might also be related to an overall population decline.

Also the Tundra Bean Goose has gone through a period of short-stopping since the 1940s, during which the Spanish wintering population vanished (Persson \& Urdiales 1995). Instead, they started to spend the winter in Germany and the Netherlands (van den Bergh 1999). A new shift started a decade ago (Pihl \& Vikstrøm 2006, this study). Up to 9200 Tundra Bean Geese were found staging in South Sweden, especially at the Lakes Kvismaren, Östen and Tåkern, in October in the years 20092011 (Heinicke \& de Jong 2013). In November, during mild winters also in January, up to 5000 Tundra Bean Geese were recorded at Lake Hammarsjön during the same period of time (Heinicke \& de Jong 2013). Regular staging of Tundra Bean 
Geese in autumn is a new phenomenon in South Sweden. During field checks of feeding bean geese at all main staging areas for Bean Geese in South Sweden in October 2003, a total of 38648 Taiga Bean Geese but only 106 Tundra Bean Geese were recorded (Leo van den Bergh in litt.). Of these Tundra Bean Geese, ten were found at the four aforementioned lakes.

Range changes in autumn and winter can be brought about in a short period of time (Owen 1980). The Tundra Bean Goose is not the only recent example of such a change in South Sweden. The total number of Barnacle Geese counted during mid-monthly counts in Sweden had up to 1999 never exceeded 5000 birds (Nilsson 2000). In November 2000, more than 55000 Barnacles were counted (Nilsson 2001). Since then, the counted numbers have remained on a high level, with peak counts of 201000 birds in south Sweden in November 2012 (Nilsson 2013a), of 132000 in south-west Scania in October 2012 (Kampe-Persson 2013a) and of 26000 in north-east Scania in November 2013 (www.spoven.com).

Milder winters in south Sweden may lead to further re-distributions of the goose populations. The Tundra Bean Goose might replace the Taiga Bean Goose as the most numerous wintering goose species in north-east Scania. Also the Pink-footed Goose may become more numerous, partly as a response to the implementation of the management plan for the Svalbard population (Madsen \& Williams 2012). In either case, there are good reasons to continue the monitoring of staging and wintering geese.

\section{Taiga Bean Goose}

Except for the census area Hammarsjön during the last decade and a few staging flocks in the other areas, the Tundra Bean Goose has been quite rare in north-east Scania (Persson 1990, 1995, this study). Therefore, with the exception of the census area Hammarsjön during the last decade, there are good reasons to accept the count data for Bean Goose as good representatives of the true numbers of Taiga Bean Geese.

North-east Scania is beyond dispute an area of international importance for staging and wintering Taiga Bean Geese. In most of the last 25 seasons, the number of Taiga Bean Geese in north-east Scania peaked at about $20 \%$ of the total Western Palearctic population. Except for Hammarsjön from 2004/2005 onwards, each of the five main census areas regularly housed more than one per- cent of the world population, Trolle-Ljungby often 10-19 percent, during the same period of time.

While changes in the overall distribution during the non-breeding season were brought about by short-stopping, the local and regional occurrence patterns depended on a set of factors. The main requirements of a goose during the non-breeding season are a safe night roost and suitable feeding grounds situated not too far from the roost (Owen 1980). North-east Scania is well provided with suitable roosts, with many lakes and a shallow coast, partly rich in low uninhabited islands. Food choice of the Taiga Bean Goose has been studied in Scania since the mid-1940s (Nordquist 1947b, Markgren 1963, Mellquist \& Nilsson 1968, Persson 1982, 1989, Nilsson \& Persson 1984, 1991, 2000, Nilsson \& Kampe-Persson 2013). In the light of these studies, it is possible to follow how northeast Scania developed into a region of international importance for the Taiga Bean Goose.

Natural grasslands and fields of clover were the main feeding habitats for Taiga Bean Geese in both autumn and winter before the 1960s (Markgren 1963). In spring, natural grasslands were and still are the preferred feeding habitat (Markgren 1963, Persson 1982, 1989). Large extensions of grasslands along River Helgeå offer a plausible explanation to the importance of the area for staging geese in the 1950s and also to why the numbers were larger in spring than in autumn (Mathiasson 1963, Table 4). In the Trolle-Ljungby area, on the other hand, the acreage of natural grasslands was quite low and very few Taiga Bean Geese staged there up to the early 1960s (Mathiasson 1963). No bean geese at all were recorded in this area in the years 1841-1866 (Wallengren 1849, 1853, 1866, Gadamer 1852, 1853).

Taiga Bean Geese used agricultural fields in Scania for feeding already two centuries ago (Nilsson 1835). However, it was the mechanisation of the agriculture during the post-war period (Myrdal \& Morell 2011) that made farmland feeding possible on a larger scale. Mechanical harvesting of potatoes and sugar beet leaves large amounts of spill for the geese to exploit (Persson 1982, 1989, Nilsson \& Persson 1984, 1991, 2000, Nilsson \& KampePersson 2013). Such spill made it possible for the Taiga Bean Goose to start using the Trolle-Ljungby area for staging in the 1960s or early 1970s (Table 4 ). With a rich food supply and a safe night roost nearby, the Trolle-Ljungby area developed into a staging and wintering area for large numbers of Taiga Bean Geese.

Hunting has been singled out as the factor during 
the non-breeding season having the largest negative impact on Taiga Bean Geese from both the western and eastern part of the breeding range (Huyskens 1999). Relevant data about hunting bags and other effects of hunting are scanty however. Besides killing birds hunting can have a negative impact by injuring birds, dissolving pair bonds and other social units, causing birds to desert a haunt completely (Ogilvie 1968), increasing the amount of time spent in flight or in alert positions and making birds keep larger distances to humans, cars and sites where hunters might hide (Karlsson et al. 1978). The latter factor significantly reduces the area available for feeding, sometimes forcing geese to leave an area altogether. Disturbance caused by hunting as well as interruption of pair bonds can significantly reduce the number of fledged young produced during the following breeding season (Persson 1999, Nilsson \& Persson 2001). In north-east Scania, the hunting pressure seems to have been quite low but information is only available from Trolle-Ljungby Manor, an entailed estate in the Trolle-Ljungby area, comprising about 12000 ha.

During the years when the open season was restricted to the first three weeks of November (1960-1991), bean geese were usually hunted during only two days in this large estate. Later, when the length of the open season had been extended to three months (October-December), hunting was reduced to one day a year (New Year's Eve). As only geese landing at pre-dug holes in agricultural fields were shot at, scared birds could search refuge at the night roost. There, they could wait undisturbed until the hunting stopped at 11 a.m. That a majority of the Taiga Bean Geese can leave an area altogether during the first hunting day was observed in other parts of Scania (Nilsson \& Persson 1978). Hunters that did not follow the local ethical rules, designed to keep the number of injured birds at a minimum, were not invited to future goose hunting parties at Trolle-Ljungby Manor (Lars Liljenberg pers. comm.). Among Taiga Bean Geese shot with a rifle in south-west Scania, mainly after the closure of the open seasons of 1978 and 1979, $28 \%$ of the first calendar-year birds and $62 \%$ of the older birds carried 1-12 lead pellets in their tissues (Jönsson et al. 1985). So, in spite of the fact that often quite large numbers of geese were bagged during a hunting day in the Trolle-Ljungby area, the geese remained in the area.

Inter-specific competition may occur among feeding geese. Several spring staging sites in Norway that earlier were used by Pink-footed Geese are nowadays used by Barnacle Geese (Ingunn Tombre pers. comm.). The Pink-footed Geese are excluded from these sites as the Barnacle Geese graze the vegetation too short for the Pink-footed Geese to feed on. Shortly after that a mixed flock has landed in a field, all Pink-footed Geese are found at the edge of the flock. Also in Scania, where often up to six or seven species feed in the same field in autumn and winter, it is normal to find the different species separated from each other. When the species occur in low numbers, such a separation can be due to "sub-flocking", that closely related individuals stay together (Raveling 1969, Rutschke 1982, Nilsson \& Persson 1992). Another explanation has to be sought when the species occur in large numbers. One suggestion is that each species avoid species with higher pecking and pacing rates (Madsen 1985). This avoidance may also be related to how dense the feeding flocks are, because fast-feeding species keep a shorter inter-individual distance than slow-feeding species (pers. obs.). The Taiga Bean Geese are, in either case, at a disadvantage as they have lower pecking and pacing rates and keep a longer inter-individual distance than Barnacle Geese, White-fronted Geese, Pink-footed Geese and Tundra Bean Geese (pers. obs).

However, for inter-specific competition to be present, food should be limiting. Food supplies are nowadays usually superabundant during the nonbreeding season but there might be two annual bottlenecks. First, when the harvested fields are depleted or ploughed. Later, when all fields with winter cereals have been grazed. Due to population increases among staging and wintering geese in north-east Scania during the last decades, November 2013 and December 2013 were the two months with the largest counted totals so far (www.spoven. com), inter-specific competition may be an important factor in the observed distribution patterns.

Food depletion is the most plausible reason for the progressively earlier seasonal peak counts in north-east Scania, due to the increasing overall food intake from increasing goose numbers. Each switch of the seasonal peak count to an earlier month coincided with a marked increase in the total number of Bean Geese counted in the first months of the season. Also numbers of other goose species staging and wintering in north-east Scania have increased markedly since the mid-1990s (Kampe-Persson et al. 2007, www.spoven.com), all species feeding on the same food sources (Nilsson \& Kampe-Persson 2013). Apparently, when the energy-rich food (harvest spill) was depleted, some of the geese moved on southwards/south-westwards, while the others switched to less profitable food sources (fields with 
winter cereal). As long as Taiga Bean Geese have access to fields with winter cereal and experience little disturbance, the geese are not in want. Frequent exposure to disturbance might, however, force the birds to leave the haunt as they no longer can balance their energy budget (Persson 1989).

Another factor reducing the availability of the felds for feeding geese are actions taken by farmers to keep them away from growing crops. It was after the agricultural revolution in the 18th and 19th centuries, that farmers started to scare the geese away from their fields to alleviate crop damage. In north-central Spain, the villages employed boys, so called ganseros, to keep the geese from the autumn-sown crops (Madoz 1849). In 2004, north-east Scania got its own gansero. Under the auspices of a regional management plan (Edberg 2004), this person has since the 2004/2005 season helped the farmers to scare the Greylag Geese away from sensitive crops. However, as all goose species use the very same food sources during the non-breeding season, often in mixed flocks (Nilsson \& Kampe-Persson 2013), all species are affected even if only one of them is actively scared. So, the disappearance of the Taiga Bean Goose from cultivated fields at Lake Hammarsjön and a decline in the numbers of staging and especially wintering Taiga Bean Geese in north-east Scania since 2004 might be more than a coincidence.

In the 1990s, the number of wintering Greylag Geese increased in the Netherlands at the same time as the number declined in south-west Spain. Birds followed all-year-round showed that these numerical changes were due to birds wintering in the Netherlands had higher survival and higher breeding output, at the same time as they recruited into the breeding population at an earlier age (Nilsson \& Persson 1996). Corresponding data are lacking for Taiga Bean Geese wintering in north-east Scania. In fact, even the origin of the birds is poorly known. A number of individuals neck-collared at breeding grounds in Finland have been re-sighted here (Nilsson 2011) and in January, low numbers of large-sized birds with large, mainly black bills, strongly indicating an eastern origin (van den Bergh 2003a) often were observed (Hakon KampePersson unpubl.). Whether or not the majority of the unmarked birds originated from the same areas as the marked ones is unknown. Uncertainty regarding origin of the birds makes it impossible to determine if the Taiga Bean Geese that wintered at Lake Hammarsjön switched to another wintering area or if that part of the population has markedly declined in number.

\section{Acknowledgements}

This contribution had been impossible without the devotion of the members of Nordöstra Skånes Fågelklubb, who month after month, some of them all the time since November 1976, have counted all staging and wintering geese within their census area. The counts were supported by the Swedish Hunters Association ("Jägartjugan"). Frank Abrahamson, Leo van den Bergh, Sven Birkedal, Greger Flyckt, Thomas Heinicke and Georges Huyskens provided field data about the occurrence of Taiga and Tundra Bean Geese, while Åke Andersson provided data about hunting bags at TrolleLjungby Manor. Gundega Kampe-Persson helped to prepare the figure. Comments by Adriaan de Jong on an earlier version significantly improved the presentation.

\section{References}

Aarvak, T. \& Øien, I.J. 2009. Monitoring of Bean Goose in Finnmark County, Norway - results from 2008. NOF rapportserie repot No. 2-2009, 10 pp. Norsk Ornitologisk Forening, Klæbu.

Alphéraky, S. 1905. The geese of Europe and Asia. Rowland Ward, London.

Banks, R.C., Chesser, R.T., Cicero, C., Dunn, J.L., Kratter, A.W., Lovette, I.J., Rasmussen, P.C., Remsen, J.V.Jr., Rising, J.D., \& Stotz, D.F. 2007. Forty-eigth Supplement to the American Ornithologists' Union Check-list of North American Birds. The Auk 124: 1109-1115.

Bergh, L. van den 1999. Tundra Bean Goose Anser fabalis rossicus. Pp. 38-66 in Goose populations of the Western Palearctic (Madsen, J., Cracknell, G. \& Fox, A.D., eds.). Wetlands International Publication No. 48. Wetlands International \& National Environmental Research Institute, Wageningen \& Rønde.

Bergh, L. van den 2003a. De West-Siberische Taigagans of Johansens Gans Anser fabalis johanseni. het Vogeljaar 51: 58-64. (Dutch with English summary).

Bergh, L. van den 2003b. De Oost-Sibirische Taigagans of Middendorff's Gans Anser fabalis middendorffii. het Vogeljaar 51: 243-249. (Dutch with English summary).

Bergh, L. van den 2004. De Oost-Sibirische Toendarietgans Anser serrirostris serrirostris. het Vogeljaar 52: 14-22. (Dutch with English summary).

Bernsmo, J., Erterius, D., Flyckt, G., Hellquist, A., Holmgren, T., Larsson, H. McIvor, G., Strandberg, R., Söderberg, P. \& Österblad, P. 2005. Fågelrapport 2004. Pp. 77-183 in Fåglar i Skåne 2004 (Svensson, M., Lorentzon, J. \& Erterius, D., eds.). Anser, supplement 52, Lund.

Bernsmo, J., Elleström, O., Erterius, D., Flyckt, G., Hellquist, A., Holmgren, T., Jönsson, O., Larsson, H., McIvor, G., Segergren, J., Strandberg, R., Stenlund, J., Svanberg, T. \& Österblad, P. 2007. Fågelrapport 2006. Pp. 79-192 in Fåglar i Skåne 2006 (Svensson, M., Gustavsson, H.Å., Jönsson, O. \& Svahn, K., eds.). Anser, supplement 54, Lund. 
Bernsmo, J., Elleström, O., Erterius, D., Flyckt, G., Jönsson, O., Hellquiust, A., Holmgren, T., Lorentzon, J., McIvor, G., Segergren, J., Stenlund, J., Strandberg, R., Svanberg, T. \& Österblad, P. 2008. Fågelrapport 2007. Pp. 81-192 in Fåglar i Skåne 2007 (Gustavsson, H.-Å., Jönsson, O., Svahn, K.Ö. \& Svensson, M., eds.). Anser, supplement 56 , Lund.

Bernsmo, J., Flyckt, G., Holmgren, T., Jönsson, O., Lorentzon, J., Magnusson, S., Stenlund, J., Strandberg, R., Svahn, K.Ö., Svanberg, T., Ullman, M. \& Österblad, P. 2011. Fågelrapport 2010. Pp. 91-192 in Fåglar $i$ Skåne 2010 (Karlsson, M., Svahn, K. \& Svensson, M., eds.). Anser, supplement 61, Lund.

Bernsmo, J., Dahlén, J., Flyckt, G., Jönsson, O., Lorentzon, J., Magnusson, S., Melchert, D., Nilsson, O., Strandberg, R., Svahn, K.Ö., Svanberg, T., Ullman, M. \& Österblad, P. 2012. Fågelrapport 2011. Pp. 103-202 in Fåglar i Skåne 2011 (Karlsson, M. \& Svahn, K., eds.). Anser, supplement 64, Vellinge.

Burgers, J., Smit, J.J. \& van der Voet, H. 1991. Origins and systematics of two types of the Bean Goose Anser fabalis (Latham, 1787) wintering in the Netherlands. Ardea 79: 307-315.

Cramp, S. 1977. Handbook of the Birds of Europe, the Middle East and North Africa. The Birds of the Western Palearctic. Volume 1. Ostrich to Ducks. Oxford University Press, Oxford.

Drent, R.H. 1996. Energetic bottlenecks in the annual cycle of migratory wildfowl (Anatidae). Gibier Faune Sauvage, Game Wildlife 13: 615-634.

Drent, R.H., Fox, A.D. \& Stahl, J. 2006. Traveling to bread. Journal of Ornithology 147: 122-134.

Dzubin, A., Boyd, H. \& Stephen, W.J. 1975. Blue and Snow Goose distribution in the Mississippi and Central Flyway. Canadian Wildlife Service Preliminary Report 1, 88 pp.

Edberg, R. 2004. Förvaltningsplan för grågås. Länsstyrelsen i Skåne län, Kristianstad.

Filchagov, A.V., Bianki, V.V. \& Mikhailov, K.T. 1985. Bean Goose Anser fabalis on the Kola Peninsula. Ornitologija 20: 26-32. (In Russian).

Flyckt, G., Hellquist, A., Holmgren, T., Holmqvist, N., Larsson, H., Strandberg, R., Svanberg, T., Söderberg, P. \& Österblad, P. 2004. Fågelrapport 2003. Pp. 89-192 in Fåglar i Skåne 2003 (Erterius, D. \& Lorentzon, J., eds.). Anser, supplement 48, Halmstad.

Fox, A.D., Ebbinge, B.S., Mitchell, C., Heinicke, T., Aarvak, T., Colhourn, K., Clausen, P., Dereliev, S., Faragó, S., Koffijberg, K., Kruckenberg, H., Loonen, M.J.J.E., Madsen, J., Mooij, J., Musil, P., Nilsson, L., Pihl, S. \& van der Jeugd, H. 2010. Current estimates of goose population sizes in western Europe, a gap analysis and an assessment of trends. Ornis Svecica 20: 115-127.

Gadamer, H. 1852. Angabe der im nordöstlichen Schonen vorkommenden Vögel mit besonderer Rücksicht auf die hier brütenden. Naumannia 2(3): 1-19.

Gadamer, H. 1853. Ornitologische Miscellaneen. Naumannia 3: 406-419.

Germundsson, T. \& Schlyter, P. 1999. Atlas över Skåne. Lantmäteriet \& Sydsvenska Geografiska Sällskapet, Vällingby.

Heinicke, T. 2004. Neue Erkenntnisse zum Auftreten der Waldsaatgans in Mecklenburg-Vorpommern. Ornithologischer Rundbrief für Mecklenburg-Vorpommern 45:
3-18.

Heinicke, T. 2009. Status of the Bean Goose Anser fabalis wintering in central Asia. Wildfowl 59: 77-99.

Heinicke, T. 2010. Bean Goose neck-banding projects in Europe - a recent overview. Goose Bulletin 10: 38-43.

Heinicke, T. \& de Jong, A. 2013. Tundra Bean Geese Anser fabalis rossicus in central and southern Sweden autumn 2009-spring 2013. Ornis Norvegica 36: 32-37.

Heinicke, T., Mooij, J. \& Steudtner, J. 2005. Identification of Bean Goose (Anserf. fabalis, A. f. rossicus) and Pink-footed Goose (Anser brachyrhynchus) and their occurrence in East Germany. Hiddensee Ornithological Station ring recovery report 3/2005. Mitteilungen Vereins der Sächsischen Ornithologen 9: 533-553. (German with English summary).

Huyskens, P.R.G. 1986. The Bean Geese problem in Europe. Oriolus 52: 105-256. (Flemish with English summary).

Huyskens, G. 1999. The Taiga Bean Goose (Anser fabalis): a species that needs world-wide protection. Georges Huyskens, Kapellen, Belgium.

Impe, J. Van 1980a. Etude de deux populations de l'Oie des moissons Anser fabalis. Alauda 48: 1-20. (French with English summary).

Impe, J. Van 1980b. Ecologie et ethologie des Oies des moissons, Anser fabalis fabalis et Anser fabalis rossicus. Le Gerfaut 70: 499-558. (French with English summary).

Jensen, B., Markgren, G. \& Mathiasson, S. 1962. A DanishSwedish goose census in 1960. Vår Fågelvärld 21: 182189. (Swedish with English summary).

Jong, A. de, Heinicke, T., Aarvak, T. \& Øien, I.J. 2013. Movements of Tundra Bean Goose Anser fabalis rossicus neck-banded in northern Scandinavia. Ornis Norvegica 36: $28-31$.

Jägerskiöld, L.A. \& Kolthoff, G. 1926. Nordens fåglar. Albert Bonniers Förlag, Stockholm.

Jönsson, B., Karlsson, J. \& Svensson, S. 1985. Incidence of lead shot in tissues of the Bean Goose (Anser fabalis) wintering in South Sweden. Swedish Wildlife Research 13: 259-271.

Kampe-Persson, H. 2002. Anser anser Greylag Goose. BWP Update 4: 181-216.

Kampe-Persson, H. 2007. Gåsinventeringar i Nordostskåne 1956-2006. Spoven 31: 21-31.

Kampe-Persson, H. 2010a. Geese in Latvia - past, present and future. Goose Bulletin 11: 18-27.

Kampe-Persson, H. 2010b. River Tolånga - a site of international importance for wintering Taiga Bean Geese Anser fabalis fabalis. Anser 49: 227-230. (Swedish with English summary).

Kampe-Persson, H. 2011. How large proportion of the Bean Geese counted in Sweden was made up of Taiga Bean Geese Anser fabalis fabalis? Ornis Svecica 21: 58-60. (Swedish with English summary).

Kampe-Persson, H. 2013a. Från havregås till sockerbetsgås - den vitkindade gåsen som höstrastfågel i södra Skåne. Anser 52: 5-11.

Kampe-Persson, H. 2013b. Gåsräkning i Lettland respektive Nordostskåne. Spoven 37(4): 25-31.

Kampe-Persson, H. \& Lerner, H. 2007. Occurrence of hybrid geese in Sweden - a conservation problem? Ornis Svecica 17: $154-186$.

Kampe-Persson, H., Bildström, L. \& Bildström, M. 2005. Can nesting competition with Whooper Swan Cygnus 
cygnus cause a decline of the Swedish Taiga Goose Anser fabalis fabalis population? Ornis Svecica 15: 119-121.

Kampe-Persson, H., Jungbeck, U., Svensson, Å. \& Valfridsson, E. 2007. Rastande och övervintrande gäss i Nordostskåne 1976/77-2006/07. Spoven 31: 155-167.

Karlsson, J., Lones, J. \& Manson, M. 1978. Size and shape of the feeding areas used by the bean goose Anser fabalis during the autumn stay in Skåne, South Sweden. Anser 17: 146-153. (Swedish with English summary).

Karlsson, M., Bernsmo, J., Flyckt, G., Holmgren, T., Jönsson, O., Lorentzon, J., Magnusson, S., Stenlund, J., Strandberg, K., Svahn, K., Svanberg, T., Ullman, M. \& Österblad, P. 2010. Fågelrapport 2009. Pp. 83-192 in Fåglar i Skåne 2009 (Karlsson, M., Svahn, K. \& Svensson, M., eds.). Anser, supplement 60, Lund.

Kear, J. 1965. Recent changes in Scottish barley acreages and the possible effect on wild geese. Scottish Birds 3: 288-292.

Klafs, G. \& Stübs, J. 1979. Die Vogelwelt Mecklenburgs. Avifauna der Deutschen Demokratischen Republik. Vol. 1. AULA-Verlag, Wiesbaden.

Koffijberg, K., Hustings, F., de Jong, A., Hornman, M. \& van Winden, E. 2011. Recent developments in numbers and distribution of Taiga Bean Goose Anser fabalis in The Netherlands. Limosa 84: 117-131. (Dutch with English summary).

Liebherr, H. \& Rutschke, E. 1993. Ergebnisse morphometrischer Untersuchungen an Saatgänsen - Anser fabalis. Ornithologische Mitteilungen 45: 299-304.

Litzbarski, H. 1974. Taxonomische und biometrische Untersuchungen an der Saatgans Anser fabalis (Latham 1787). Beiträge zur Vogelkunde 20: 391-411.

Madoz, P. 1849. Diccinario geográfico-estadistico-histórico de España y sus posesiones de ultramar. Vol. XII. Imprenta del Diccinario geográfico-estadistico-histórico de d. Pascual Madoz, Madrid.

Madsen, J. 1985. Habitat selection of farmland feeding geese in West Jutland: an example of a niche shift. Ornis Scandinavica 16: 140-144.

Madsen, J. \& Williams, J.H. 2012. International Species Management Plan for the Svalbart Population of the Pink-footed Goose Anser brachyrhynchus. AEWA Technical Series No. 48. Bonn, Germany.

Markgren, G. 1963. Migrating and wintering geese in southern Sweden. Ecology and Behaviour studies. Acta Vertebratica 2: 297-418.

Mathiasson, S. 1963. The Bean Goose, Anser fabalis (Latham), in Skåne, Sweden, with remarks on occurrence and migration through northern Europe. Acta Vertebratica 2: 418-533.

Mellquist, H. \& von Bothmer, R. 1982. Sädgåsen som häckfăgel i Sverige. Pp. 23-28 in De svenska gässen: förekomst, ekologi, betesskador, jakt och vård. (Svensson, S., ed.). Vår Fågelvärld Supplement 9.

Mellquist, H. \& Nilsson, B. 1968. The Vomb Area as Halting and Wintering Habitat of Bean Goose (Anser fabalis). Vår Fågelvärld 27: 220-230. (Swedish with English summary).

Mitchell, C., Colhoun, K., Fox, A.D., Griffin, L., Hall, C., Hearn, R., Holt, C., \& Walsh, A. 2010. Trends in goose numbers wintering in Britain and Ireland, 1995 to 2008. Ornis Svecica 20: 128-143.

Mitchell, D. \& Vinicombe, K.E. 2012. Birds of Britain: the complete checklist. Fourth edition. Warners Group Publications, London.

Myrdal, J. \& Morell, M. 2011. The Agrarian History of Sweden: From 4000 BC to AD 2000. Nordic Academic Press, Lund.

Månsson, K. 1977. Egesideområdet - idag och för 15 år sedan. Information från Nordöstra Skånes Fågelklubb 1: 14-20.

Naumann, J.F. 1842. Johann Andreas Naumann's Naturgeschichte der Vögel Deutschlands, nach eigenen Erfahrungen entworfen. Durchaus umgearbeitet, systematisch geordnet, sehr vermehrt, vervollständigt, und mit getreu nach der Natur eigenhändig gezeichneten und gestochenen Abbildungen aller deutschen Vögel, nebst ihrer Hauptverscheidenheiten, aufs Neue herausgegeben von dessen Sohne Johann Friedrich Naumann. Vol. XI. Leipzig.

Neideman, C. \& Svensson, Å. 1976. Örn- och gåsinventering 1976-11-27. Information från Nordöstra Skånes $F a ̊-$ gelklubb 0: 7 .

Nilsson, L. 1984. Migrations of Fennoscandian Bean Geese Anser fabalis. Swedish Wildlife Research 12: 83-106.

Nilsson, L. 2000. Changes in numbers and distribution of staging and wintering goose populations in Sweden, 1977/78-1998/1999. Ornis Svecica 10: 33-49.

Nilsson, L. 2001. Invasion av vitkindade gäss i Sydsverige. Vår Fågelvärld 60(1): 18-19.

Nilsson, L. 2006. Changes in migration patterns and wintering areas of South Swedish greylag geese Anser anser. Pp 514-516 in Waterbirds around the world (Boere, G.C., Galbraith, C.A. \& Stroud, A.D., eds.). The Stationary Office, Edinburgh.

Nilsson, L. 2011. The migrations of Finnish Bean Geese Anser fabalis in 1978-2011. Ornis Svecica 21: 157-166.

Nilsson, L. 2013a. Staging and wintering goose populations in Sweden 1977/78-2011/12. Ornis Svecica 23: 3-45.

Nilsson, L. 2013b. International counts of waterbirds, geese and cranes in Sweden. Annual report 2012/2013, 56 pp. Department of Biology, Lund University, Lund. (Swedish with English summary).

Nilsson, L. \& Kampe-Persson, H. 2013. Field choice of autumn staging and wintering geese in south-western Sweden 1977/78-2011/12. Ornis Svecica 23: 46-60.

Nilsson, L. \& Persson, H. 1978. Numbers and movements among geese resting and wintering in Skåne, South Sweden, 1977-1978. Anser 17: 139-145. (Swedish with English summary).

Nilsson, L. \& Persson, H. 1984. Non-breeding distribution, numbers and ecology of Bean Goose, Anser fabalis, in Sweden. Swedish Wildlife Research 13: 107-170.

Nilssson, L. \& Persson, H. 1991. Selection and exploitation of feeding areas by staging and wintering geese in southernmost Sweden. Ornis Svecica 1: 81-92.

Nilsson, L. \& Persson, H. 1992. Feeding areas and local movement patterns of post-breeding Greylag Geese in South Sweden. Ornis Svecica 2: 77-90.

Nilsson, L. \& Persson, H. 1996. The influence of the choice of winter quarters on the survival and breeding performance of greylag geese (Anser anser). Gibier Faune Sauvage, Game Wildlife 13: 557-571.

Nilsson, L. \& Persson, H. 2000. Changes in field choice among staging and wintering geese in southwestern Scania, south Sweden. Ornis Svecica 10: 161-169. 
Nilsson, L. \& Persson, H. 2001. Change of mate in a Greylag Goose Anser anser population: effects of timing on reproductive success. Wildfowl 52: 31-40.

Nilsson, L., van den Bergh, L. \& Madsen, J. 1999. Taiga Bean Goose Anser fabalis fabalis. Pp. 20-36 in Goose populations of the Western Palearctic (Madsen, J., Cracknell, G. \& Fox, A.D., eds.). Wetlands International Publication No. 48. Wetlands International \& National Environmental Research Institute, Wageningen \& Rønde.

Nilsson, L., de Jong, A., Heinicke, T. \& Sjöberg, K. 2010. Satellite tracking of Bean Geese Anser fabalis fabalis and $A$. f. rossicus from spring staging areas in northern Sweden to breeding and moulting areas. Ornis Svecica 20: 184-189.

Nilsson, S. 1835. Skandinavisk fauna. Foglarna. Vol. 2. C.W.K. Gleerups Förlag, Lund.

Nordqvist, G. 1947a. Hammarsjön och Nymö mosse. Pp. 119-126 in Natur $i$ Skåne (Hanström, B. \& Curry-Lindahl, K., eds.). Bokförlaget Svensk Natur, Stockholm.

Nordqvist, G. 1947b. Gäss i Skåne. Pp. 320-330 in Natur $i$ Skåne (Hanström, B. \& Curry-Lindahl, K., eds.). Bokförlaget Svensk Natur, Stockholm.

Ogilvie, M.A. 1968. The numbers and distribution of the European White-fronted Goose in Britain. Bird Study 15: $2-18$.

Ogilvie, M.A. 1978. Wild Geese. T. \& A.D. Poyser, Berkhamsted.

Owen, M. 1980. Wild Geese of the world. B.T. Batsford, London.

Parslow-Otsu, M. 1991. Bean Geese in the Yare Valley, Norfolk. British Birds 84: 161-170.

Parslow-Otsu, M. \& Kjeldsen, J.P. 1992. Laplandske Sædgæs i Nordvestjylland. Dansk Ornitologisk Forenings Tidskrift 86: 104-106.

Persson, H. 1982. Sädgässens fältval i Skåne. Pp. 75-78 in De svenska gässen: förekomst, ekologi, betesskador, jakt och vård. (Svensson, S., ed.). Vår Fågelvärld Supplement 9.

Persson, H. 1989. Food selection, movements and energy budgets of staging and wintering geese on South Swedish farmland. Dissertation. Department of Ecology, Lund University.

Persson, H. 1990. Occurrence of the Tundra Bean Goose $A n-$ ser fabalis rossicus in Sweden. Anser 29: 237-244. (Swedish with English summary).

Persson, H. 1995. Tundrasädgåsen Anser fabalis rossicus i nordöstra Skåne. Spoven 19: 3-7.

Persson, H. 1997a. Halsringmärkt tundrasädgås i TrolleLjungby. Spoven 21:10.

Persson, H. 1997b. Occurrence of the Tundra Bean Goose Anser serrirostris rossicus in Scania, 1974-1996. Anser 36: 179-184. (Swedish with English summary).

Persson, H. 1999. La chasse á l'Oie cendrée Anser anser en FrancI.ou de l'exploitation excessive d'une ressource naturelle. Alauda 67: 223-230.

Persson, H. \& Persson, M. 1992. Are Levrasjön, Valjeviken and Sölvesborgsviken of internationell importance for staging and wintering waterfowl? Anser 31: 245-250. (Swedish with English summary).

Persson, H. \& Urdiales, C. 1995. The disappearance of the Tundra Bean Goose Anser fabalis rossicus from the Iberian Peninsula. IWRB Goose Research Group Bulletin 6: 17-19.
Pihl, S. \& Vikstrøm, T. 2006. Gæs og svaner i mandtal. Fugle og Natur 26(4): 24-25.

Pirkola, M.K. \& Kalinainen, P. 1984. The status, habitats and productivity of breeding populations of Bean Goose, Anser fabalis fabalis, in Finland. Swedish Wildlife Research 13: 9-48.

Raveling, D.G. 1969. Roost sites and flight patterns of Canada Geese in winter. Journal of Wildlife Management 33: 319-330.

Reeves, H.M., Dill, H.H. \& Hawkins, A.S. 1968. A case study in Canada Goose management: the Mississippi Valley population. Pp. 150-165 in Canada Goose Management (Hine, R.I. \& Schoenfeld, C., eds.). Dembar Education, Madison, Wisconsin.

Rutschke, E. 1982. Stability and dynamics in the social structure of the Greylag Goose (Anser anser). Aquila 89: 39-55.

Rutschke, E. 1983. Die Vogelwelt Brandenburgs. Avifauna der Deutschen Demokratischen Republik. Vol. 2. VEB Gustav Fischer Verlag, Jena.

Rutschke, E. 1987. Die Wildgänse Europas. VEB Deutscher Landwirtschaftsverlag, Berlin.

Sangster, G. \& Oreel, G.J. 1996. Progress in taxonomy of Taiga and Tundra Bean Geese. Dutch Birding 18: 310 316.

Sangster, G., Hazevoet, C.J., van den Berg, A.B., Roselaar, C.S. \& Sluys, R. 1999. Dutch avifaunal list: species concepts, taxonomic instability, and taxonomic changes in 1977-1998. Ardea 87: 139-165.

Sangster, G., van den Berg, A.B., van Loon, A.J. \& Roselaar, C.S. 2003. Dutch avifaunal list: taxonomic changes in 1999-2003. Ardea 91: 279-286.

Saurola, P., Valkama, J. \& Velmala, W. 2013. The Finnish Bird Ringing Atlas. Vol. 1. Finnish Museum of Natural History and Environment, Helsinki. (Finnish with English summary).

Skyllberg, U. \& Tjernberg, M. 2008. Spring staging of Taiga Bean Goose Anser f. fabalis in southern Sweden 2007 estimate of the size of populations using the western and central flyways. Ornis Svecica 18: 45-51.

Skyllberg, U., Hansson, P. \& Bernhardtson, P. 2009a. På besök i den skandinaviska taigasädgåsens vinterkvarter. $V a ̊ r$ Fågelvärld 68(2): 24-27.

Skyllberg, U., Nousiainen, I., Hansson, P., Bernhardtson, P., Andersson, Ö. \& Nordlund, M. 2009b. Spring migration of the Taiga Bean Goose Anser f. fabalis along the "Western Flyway" in northern Sweden: numbers in 2003-2008 and timing in comparison with the "Central Flyway" in Finland. Ornis Svecica 19: 199-204.

Svensson, Å. 1977. Gåsinventeringar 1977-78. Information från Nordöstra Skånes Fågelklubb 1: 27-28.

Swegen, H. 1963. Egesideområdet - en östskånsk fågellokal. Fauna och Flora 58: 210-235.

Söderberg, R. 1917. Flyttfågelstudier. Fauna och Flora 12: 49-62 + 140-143.

Tjernberg, M., Ahlén, I., Andersson, Å., Eriksson, M.O.G., Nilsson, S.G. \& Svensson, S. 2010. Birds. Pp. 307-315 in Rödlistade arter i Sverige 2010 (Gärdenfors, U., ed.). ArtDatabanken, SLU, Uppsala.

Tombre, I.M., Högda, K.A., Madsen, J., Griffin, L.R., Kuijken, E., Shimmings, P., Rees, E. \& Verscheure, C. 2008. The onset of spring and timing of migration in two arctic breeding goose populations: the pink-footed goose Anser 
brachyrhynchus and the barnacle goose Branta leucopsis. Journal of Avian Biology 39: 691-703.

Tveit, G. 1984. Autumn migration, wintering areas and survival of Bean Geese Anser fabalis marked on the moulting grounds in Finnmark, North Norway. Swedish Wildlife Research 13: 73-82.

Wallengren, H.D.J. 1849. Foglar i nordöstra Skåne. Öfversigt af Kongliga Vetenskaps-Akademiens Förhandlingar 1849 .

Wallengren, H.D.J. 1853. Foglar i nordöstra Skåne. Öfversigt af Kongliga Vetenskaps-Akademiens Förhandlingar 1853.

Wallengren, H.D.J. 1866. Nordöstra Skånes Fauna. Öfversigt af Kongliga Vetenskaps-Akademiens Förhandlingar 1866.

\section{Sammanfattning}

Här redovisas de månatliga inventeringar av sädgäss som medlemmar av Nordöstra Skånes Fågelklubb genomfört under ickehäckningstid i Nordostskåne (kommunerna Bromölla och Kristianstad, samt ett mindre område i kommunerna Östra Göinge och Hässleholm) sedan november 1976. Målet var att sätta in dessa resultat i ett historiskt, ekologiskt och internationellt sammanhang. Av den anledningen redovisas även samtliga kända inventeringar från åren 1947-1976, dels av området som helhet och dels av enskilda gåsområden (Tabell 4).

Inventeringarna genomfördes månaderna oktober-mars/april på lördag förmiddag under den helg som inföll närmast den 15:e. Före den första inventeringen delades regionen in i fem räkningsområden, vilka förblivit oförändrade. Ett sjätte räkningsområde med två lokaler har tillkommit, Näsum från och med oktober 2003 och Ivö från och med december 2006. Antalet inräknade gäss bör ses som absoluta minimisiffror, ty otjänlig väderlek och jakt medförde emellanåt att gäss blev oräknade eller oidentifierade.

Eftersom inventerarna inte skiljt på taigasädgäss (skogssädgäss) och tundrasädgäss samlades information om andelen taigasädgäss i flockarna in genom separata kontroller av rastande flockar, genomgång av jaktbyten på Trolle-Ljungby Gods samt uppgifter om flockar på minst 50 tundrasädgäss (Tabell 2 och 3). Sammantaget visade dessa uppgifter att bortsett från räkningsområde Hammarsjön från och med säsongen 2004/05 och några rastande flockar i övriga räkningsområden har tundrasädgåsen förekommit sparsamt i Nordostskåne. Med undantag för Hammarsjön från och med 2004/05 kan de inräknade sädgässen på goda grunder antas ha varit taigasädgäss. Uppgift om andelen taigasädgäss vid Hammarsjön saknas för säsongerna 2004/05-2008/09. Under de senaste fyra säsongerna har så gott som samtliga sädgäss som setts på fälten inom detta område varit tundrasädgäss medan flockar på upp till 415 taigasädgäss har setts på Rinkaby ängar och Hovby ängar.

Under åren 1947-1960 rastade sädgässen höst och vår vid Araslövsjön, Hammarsjön och Egeside. Även under de följande 16 åren ankom gässen i slutet av september och flyttade bort i början av maj, men ett ökande antal stannade kvar över vintern. Någon gång under 60 -talet eller i början av 70-talet började gässen även uppträda vid TrolleLjungby och Oppmannasjön + Råbelövsjön.

Ett flertal förändringar inträffade under de senaste 37 säsongerna. Tidigare bortflyttning om våren gjorde att antalet sädgäss $\mathrm{i}$ april minskade från drygt 5000 fåglar vid den första räkningen till knappt några alls från och med 1997. En liknande förändring om än i mindre skala kan ha skett under hösten, ty 389 fåglar inräknades i september 1977, den enda septemberräkning som genomfördes före 1993. Generellt sett räknades förre sädgäss fram till och med säsongen 1986/87 än därefter. Totalsiffror på över 22000 fåglar noterades vid fem tillfällen under perioden 1991/92-2004/05 och det högsta inräknade antalet var 24000 fåglar i december 1997. Under hårda vintar lämnade de flesta eller alla sädgäss Nordostskåne.

Bortsett från Egeside och Ivösjön uppvisar de olika räkningsområdena i stort sett samma tids- och antalsmässiga förändringar som området som helhet. Trolle-Ljungby var det område som vanligtvis hyste flest rastande och övervintrande sädgäss och säsongshögsta överskred ofta 10000 fåglar (15 802 i november 2003). Oppmannasjön + Råbelövsjön uppvisade de största mellanårsvariationerna. Under de flesta säsongerna uppgick säsongshögsta till 2 000-2 500 fåglar vid Araslövsjön + Gummastorpasjön och c:a 5000 fåglar vid Hammarsjön. Egeside har däremot varit en typisk övervintrings- och vårrastlokal med få sädgäss på hösten, ofta inga alls i oktober. Säsongshögsta uppgick under perioden 1987/88-2005/06 vanligtvis till 2500-4000 fåglar.

Under de flesta av de senaste 25 säsongerna har antalet taigasädgäss i Nordostskåne vid åtminstone någon inventering uppgått till drygt $20 \%$ av det totala antalet i Västpalearktis. Under samma period har, med undantag för Hammarsjön från och med säsongen 2004/05, vart och ett av de fem huvudräkningsområdena hyst mer än en procent av världspopulationen, Trolle-Ljungby ofta mer än tio procent. Dessa områden är således av internationell betydelse för rastande och övervintrande taigasädgäss.

Före 1960-talet födosökte sädgässen under höst 
och vinter framförallt på gräsmark och klövervallar, medan gräsmarker var det habitat som prefererades under våren, såväl då som senare. Denna preferens för gräsmarker förklarar varför sädgässen fram till och med 1960 rastade i stora flockar längs med Helgeån, samtidigt som arten knappast alls besökte Trolle-Ljungby-området. Visserligen sökte sädgäss föda på åkermark i Skåne redan för 200 år sedan, men det var först med jordbrukets mekanisering under efterkrigstiden som födosök på åkermark blev möjlig i någon större omfattning. Maskinell upptagning av potatis och sockerbetor lämnar mycket spill och det var just detta spill som möjliggjorde för gässen att börja utnyttja fälten i Trolle-Ljungby-området för födosök. Med ett rikt utbud på föda, framförallt skördespill, tillgång till en säker nattplats (skärgård) i närheten samt en utformning av jakten som inte skrämde bort gässen utvecklades Trolle-Ljunby-området till ett rast- och övervintringsområde för ett mycket stort antal taigasädgäss.

Att fåglar överger sina traditionella vinterkvarter till förmån för lokaler som ligger närmare häckningsområdena kallas med ett engelskt ord för "short-stopping". Detta fenomen har beskrivits för ett flertal arter gäss. Uppgifterna om taigasädgåsens förekomst i Nordostskåne omfattar dock, till skillnad från de publicerade fallen, även tiden innan denna utveckling inleddes. På 1950-talet utnyttjades Nordostskåne endast som rastlokal höst och vår av gäss som övervintrade i Danmark, Tyskland och Nederländerna. Stora arealer med höstsådda grödor och mildare vintrar tillät så småningom även övervintring, även om kraftigt snöfall ofta tvingade gässen söderut. Samtidigt med att villkoren för övervintring förbättrades i Nordostskåne, förbättrades längre norrut villkoren för rastande gäss, framförallt om våren. Detta ledde till att gässen började lämna området tidigare om våren. Sista fasen i den pågående utvecklingen skulle vara att taigasädgässen börjar söka sig till vinterkvarter som ligger ännu närmare häckningsområdena. Färre inräknade taigasädgäss i Nordostskåne under det senaste decenniet jämfört med närmast föregående decennium skulle kunna vara ett steg mot ett totalt försvinnande från regionen. Men färre gäss kan också bero på en populationsnedgång.

Mildare vintrar i Sydsverige kan leda till ytterligare förändringar $\mathrm{i}$ gåspopulationernas utbredning vintertid. Under det senaste decenniet har tundrasädgåsen börjat övervintra i såväl Danmark som vid Hammarsjön. I framtiden kan tundrasädgåsen komma att ersätta taigasädgåsen som den talrikaste gåsarten i Nordostskåne vintertid. Även spetsbergsgåsen kan komma att etablera sig som övervintrare i denna del av Sverige. I vilket fall som helst finns det goda skäl för medlemmarna $i$ Nordöstra Skånes Fågelklubb att fortsätta sin övervakning av rastande och övervintrande gäss. 
Appendix 1. Number of Bean Geese recorded at mid-monthly counts in the census area Trolle-Ljungby, 1976/1977-2013/-. A bar (-) indicates that no complete count was carried out that month.

Antalet sädgäss inräknade vid mittmånads-inventeringar $i$ räkningsområdet Trolle-Ljungby säsongerna 1976/1977-2013/-. Minustecken (-) anger att ingen komplett inventering genomfördes den månaden.

\begin{tabular}{|c|c|c|c|c|c|c|c|}
\hline & October & November & December & January & February & March & April \\
\hline $76 / 77$ & - & 1860 & - & 172 & - & 1663 & - \\
\hline $77 / 78$ & 930 & 3135 & 1500 & 1600 & 0 & 1500 & 1375 \\
\hline $78 / 79$ & 1135 & 1090 & 1500 & 0 & 0 & 3100 & 930 \\
\hline $79 / 80$ & 400 & 3310 & 430 & 360 & 0 & 983 & 996 \\
\hline $80 / 81$ & 731 & 2318 & 1043 & 522 & 950 & 574 & 1363 \\
\hline $81 / 82$ & 1290 & 2240 & 220 & 0 & 0 & 1865 & 1130 \\
\hline $82 / 83$ & 230 & 2400 & 3080 & 2500 & 466 & 900 & 1340 \\
\hline $83 / 84$ & 380 & 3240 & 1532 & 1755 & 810 & 1000 & 1490 \\
\hline $84 / 85$ & 460 & 2042 & 1550 & 771 & 300 & 150 & 1529 \\
\hline $85 / 86$ & 110 & 4334 & 487 & 159 & 320 & 1942 & 1850 \\
\hline $86 / 87$ & 65 & 2330 & 2533 & 0 & 0 & 0 & 480 \\
\hline $87 / 88$ & 230 & 1264 & 1481 & 2340 & 2229 & 2320 & 331 \\
\hline $88 / 89$ & 12 & 2225 & 2000 & 3022 & 3368 & 571 & 0 \\
\hline $89 / 90$ & 82 & 1572 & 3138 & 3262 & 3200 & 46 & 0 \\
\hline 90/91 & 87 & 5803 & 5690 & 4014 & 1500 & 200 & 0 \\
\hline 91/92 & 4 & 7500 & 4610 & 6895 & 4295 & 76 & 0 \\
\hline $92 / 93$ & 534 & 10655 & 3637 & 3770 & 2660 & 509 & 0 \\
\hline 93/94 & 564 & 7570 & 4920 & 3560 & 3610 & 965 & 0 \\
\hline 94/95 & 658 & 12020 & 7140 & 6955 & 3432 & 2 & 0 \\
\hline 95/96 & 0 & 6025 & 5100 & 208 & 4100 & 6674 & 66 \\
\hline 96/97 & 6 & 8850 & 10234 & 1489 & 785 & 8 & 0 \\
\hline 97/98 & 0 & 9417 & 13874 & 5314 & 1578 & 165 & 0 \\
\hline 98/99 & 0 & 12321 & 7895 & 7060 & 1686 & 0 & 0 \\
\hline $99 / 00$ & 1296 & 10092 & 4613 & 4134 & 1030 & 0 & 0 \\
\hline 00/01 & 10 & 2295 & 5792 & 5191 & 4964 & 19 & 0 \\
\hline $01 / 02$ & 10 & 8882 & 1743 & 1543 & 1430 & 0 & - \\
\hline $02 / 03$ & 392 & 5499 & 12011 & 4888 & 2908 & 7 & 0 \\
\hline $03 / 04$ & 3 & 15802 & 7990 & 5269 & 2526 & 105 & - \\
\hline $04 / 05$ & 61 & 11990 & 3687 & 1787 & 3867 & 4050 & - \\
\hline 05/06 & 0 & 1677 & 5317 & 3970 & 4598 & 1636 & - \\
\hline 06/07 & 0 & 1380 & 4391 & 752 & 2990 & 0 & - \\
\hline 07/08 & 241 & 6730 & 8318 & 1920 & 1510 & 40 & - \\
\hline 08/09 & 0 & 2400 & 8100 & 1296 & 3790 & 0 & - \\
\hline $09 / 10$ & 110 & 4423 & 6305 & 3942 & 872 & 4825 & - \\
\hline 10/11 & 1915 & 5113 & 2581 & 126 & 350 & 1593 & - \\
\hline $11 / 12$ & 980 & 6000 & 2908 & 1180 & 450 & 0 & - \\
\hline $12 / 13$ & 0 & 1888 & - & 875 & 882 & 8509 & - \\
\hline $13 / 14$ & 110 & 1485 & 12010 & - & - & - & - \\
\hline
\end{tabular}


Appendix 2. Number of Bean Geese recorded at mid-monthly counts in the census area Oppmannasjön + Råbelövsjön, 1976/1977-2013/-. A bar (-) indicates that no complete count was carried out that month.

Antalet sädgäss inräknade vid mittmånads-inventeringar i räkningsområdet Oppmannasjön + Råbelövsjön säsongerna 1976/1977-2013/-. Minustecken (-) anger att ingen komplett inventering genomfördes den månaden.

\begin{tabular}{|c|c|c|c|c|c|c|c|}
\hline & October & November & December & January & February & March & April \\
\hline $76 / 77$ & - & 554 & - & 2 & - & 840 & - \\
\hline $77 / 78$ & 0 & 75 & 15 & 205 & - & 1700 & 630 \\
\hline $78 / 79$ & 280 & - & - & 0 & 0 & 0 & - \\
\hline $79 / 80$ & 0 & 80 & 800 & 84 & 0 & 285 & 230 \\
\hline $80 / 81$ & 0 & 3 & 2 & 0 & 0 & 920 & 455 \\
\hline $81 / 82$ & 121 & 510 & 0 & 0 & 0 & 480 & 540 \\
\hline $82 / 83$ & 62 & 645 & 60 & 270 & 0 & 1025 & 515 \\
\hline $83 / 84$ & 0 & 515 & 0 & 190 & 210 & 1600 & 510 \\
\hline $84 / 85$ & 217 & 350 & 925 & 250 & 1 & 11 & 602 \\
\hline $85 / 86$ & 0 & 140 & 0 & 0 & 0 & 300 & 8 \\
\hline $86 / 87$ & 20 & 560 & 840 & 0 & 0 & 0 & 675 \\
\hline $87 / 88$ & 5 & 950 & 600 & 400 & 35 & 1175 & 350 \\
\hline $88 / 89$ & 19 & 3150 & 425 & 893 & 725 & 3 & 274 \\
\hline $89 / 90$ & 195 & 340 & 400 & 312 & 886 & 100 & 100 \\
\hline 90/91 & 75 & 1250 & 1300 & 450 & 0 & 454 & 90 \\
\hline 91/92 & 0 & 950 & 1100 & 402 & 1555 & 130 & 0 \\
\hline $92 / 93$ & 70 & 1400 & 2300 & 1500 & 80 & 80 & 0 \\
\hline 93/94 & 100 & 940 & 650 & 121 & 190 & 370 & 0 \\
\hline 94/95 & 120 & 1133 & 602 & 130 & 60 & 355 & 0 \\
\hline 95/96 & 120 & 685 & 2750 & 5 & 0 & 370 & 0 \\
\hline 96/97 & 195 & 1023 & 725 & 0 & 535 & 45 & 0 \\
\hline 97/98 & 750 & 2231 & 4850 & 2050 & 1200 & 224 & 7 \\
\hline 98/99 & 7 & 1402 & 4 & 238 & 0 & 493 & 0 \\
\hline $99 / 00$ & 422 & 1685 & 2455 & 80 & 1423 & 169 & 0 \\
\hline $00 / 01$ & 0 & 1008 & 800 & 410 & 760 & 24 & 0 \\
\hline $01 / 02$ & 0 & 2650 & 3780 & 500 & 1253 & 7 & 0 \\
\hline $02 / 03$ & 200 & 8807 & 2609 & 350 & 460 & 109 & 52 \\
\hline 03/04 & 0 & 3550 & 1070 & 803 & 760 & 2280 & - \\
\hline $04 / 05$ & 70 & 5900 & 2283 & 550 & 1158 & 378 & - \\
\hline 05/06 & 13 & 765 & 1945 & 1 & 0 & 0 & - \\
\hline 06/07 & 2 & 8150 & 2669 & 1521 & 545 & 5 & - \\
\hline 07/08 & 220 & 1990 & 77 & 1830 & 90 & 85 & - \\
\hline 08/09 & 0 & 1416 & 777 & 1240 & 1135 & 162 & - \\
\hline $09 / 10$ & 60 & 300 & 1630 & 0 & 24 & 20 & - \\
\hline $10 / 11$ & 200 & 1395 & 0 & 0 & 0 & 853 & - \\
\hline $11 / 12$ & 30 & 75 & 1500 & 560 & 52 & 2 & - \\
\hline $12 / 13$ & 0 & 65 & - & 2 & 560 & 1190 & - \\
\hline $13 / 14$ & 8 & 526 & 186 & \llcorner & - & - & - \\
\hline
\end{tabular}


Appendix 3. Number of Bean Geese recorded at mid-monthly counts in the census area Araslövsjön + Gummastorpasjön, 1976/1977-2013/-. A bar (-) indicates that no complete count was carried out that month.

Antalet sädgäss inräknade vid mittmånads-inventeringar i räkningsområdet Araslövsjön + Gummastorpasjön säsongerna 1976/1977-2013/-. Minustecken (-) anger att ingen komplett inventering genomfördes den månaden.

\begin{tabular}{|c|c|c|c|c|c|c|c|}
\hline & October & November & December & January & February & March & April \\
\hline $76 / 77$ & - & 540 & - & 69 & - & 990 & - \\
\hline $77 / 78$ & 871 & 2095 & 1366 & 864 & 140 & 1800 & 1144 \\
\hline $78 / 79$ & 490 & - & 1040 & 80 & 0 & 1000 & - \\
\hline $79 / 80$ & 400 & 1030 & 140 & 110 & 0 & 186 & 597 \\
\hline $80 / 81$ & 225 & 1650 & 7 & 500 & 787 & 1593 & 378 \\
\hline $81 / 82$ & 535 & 1600 & 1450 & 0 & 69 & 4630 & 1808 \\
\hline $82 / 83$ & 577 & 1850 & 2067 & 600 & 8 & 3127 & 982 \\
\hline $83 / 84$ & 370 & 1093 & 0 & 1191 & 11 & 1578 & 810 \\
\hline $84 / 85$ & 500 & 537 & 2817 & 0 & 0 & 361 & 350 \\
\hline $85 / 86$ & 110 & 173 & 1282 & 0 & 0 & 875 & 390 \\
\hline $86 / 87$ & 539 & 394 & 2595 & 0 & 2 & 80 & 5 \\
\hline $87 / 88$ & 12 & 454 & 1960 & 2055 & 2325 & 3204 & 0 \\
\hline $88 / 89$ & 0 & 350 & 907 & 2050 & 501 & 0 & 0 \\
\hline $89 / 90$ & 80 & 11 & 1690 & 2000 & 1945 & 0 & 0 \\
\hline 90/91 & 75 & 398 & 2155 & 2890 & 597 & 75 & 0 \\
\hline 91/92 & 1 & 540 & 1746 & 2435 & 3776 & 120 & 0 \\
\hline $92 / 93$ & 87 & 1204 & 1369 & 2170 & 2170 & 3112 & 2 \\
\hline 93/94 & 22 & 1002 & 1612 & 827 & 900 & 1116 & 2 \\
\hline 94/95 & 32 & 1445 & 1375 & 2250 & 2505 & 1 & 1 \\
\hline $95 / 96$ & 22 & 1747 & 681 & 110 & 3210 & 2833 & 8 \\
\hline 96/97 & 0 & 1021 & 2014 & 600 & 1091 & 1 & 0 \\
\hline 97/98 & 0 & 770 & 1090 & 2351 & 919 & 13 & 0 \\
\hline 98/99 & 0 & 220 & 1456 & 59 & 549 & 133 & 0 \\
\hline $99 / 00$ & 402 & 74 & 1232 & 2044 & 814 & 150 & 0 \\
\hline 00/01 & 30 & 23 & 1643 & 3486 & 2338 & 11 & 0 \\
\hline $01 / 02$ & 0 & 1554 & 1606 & 328 & 686 & 6 & 0 \\
\hline $02 / 03$ & 104 & 3350 & 2223 & 1243 & 2205 & 42 & 12 \\
\hline 03/04 & 0 & 623 & 3500 & 383 & 887 & 1950 & - \\
\hline $04 / 05$ & 86 & 1400 & 1335 & 450 & 0 & 600 & - \\
\hline 05/06 & 200 & 405 & 1835 & 14 & 417 & 150 & - \\
\hline 06/07 & 850 & 1980 & 2575 & 2386 & 2000 & 70 & - \\
\hline 07/08 & 38 & 330 & 1830 & 1819 & 620 & 11 & - \\
\hline 08/09 & 0 & 50 & 1517 & 1792 & 1533 & 0 & - \\
\hline $09 / 10$ & 0 & 363 & 2000 & 1145 & 773 & 220 & - \\
\hline 10/11 & 270 & 0 & 820 & 0 & 328 & 1283 & - \\
\hline $11 / 12$ & 68 & 2350 & 570 & 922 & 1400 & 150 & - \\
\hline $12 / 13$ & 20 & 74 & - & 400 & 1095 & 3395 & - \\
\hline $13 / 14$ & 0 & 23 & 700 & - & - & - & - \\
\hline
\end{tabular}


Appendix 4. Number of Bean Geese recorded at mid-monthly counts in the census area Hammarsjön, 1976/19772013/-. A bar (-) indicates that no complete count was carried out that month.

Antalet sädgäss inräknade vid mittmånads-inventeringar $i$ räkningsområdet Hammarsjön säsongerna 1976/1977-2013/-. Minustecken (-) anger att ingen komplett inventering genomfördes den månaden.

\begin{tabular}{|c|c|c|c|c|c|c|c|}
\hline & October & November & December & January & February & March & April \\
\hline $76 / 77$ & - & 590 & - & 189 & - & 1740 & - \\
\hline $77 / 78$ & 42 & 172 & 1000 & 2150 & 740 & 4450 & 2012 \\
\hline 78/79 & 1 & - & - & 0 & 0 & 2000 & - \\
\hline $79 / 80$ & 7 & 336 & 1805 & 1465 & 1 & 2400 & 2610 \\
\hline $80 / 81$ & 0 & 1300 & 760 & 1100 & 2200 & 1875 & 600 \\
\hline $81 / 82$ & 23 & 327 & 255 & 0 & 0 & 2370 & 970 \\
\hline $82 / 83$ & 131 & 45 & 1750 & 2427 & 128 & 4910 & 670 \\
\hline $83 / 84$ & 6 & 336 & 300 & 3491 & 2260 & 4930 & 771 \\
\hline $84 / 85$ & 380 & 952 & 4148 & 440 & 586 & 5998 & 1303 \\
\hline $85 / 86$ & 75 & 450 & 852 & 110 & 192 & 1014 & 1010 \\
\hline $86 / 87$ & 0 & 8 & 1387 & 0 & 184 & 1352 & 441 \\
\hline $87 / 88$ & 0 & 328 & 7705 & 1143 & 4831 & 4527 & 211 \\
\hline $88 / 89$ & 0 & 1375 & 4445 & 10595 & 4210 & 305 & 0 \\
\hline $89 / 90$ & 15 & 0 & 2576 & 5695 & 3808 & 62 & 0 \\
\hline 90/91 & 105 & 2350 & 4858 & 6139 & 2355 & 184 & 20 \\
\hline 91/92 & 0 & 1407 & 4978 & 8961 & 6228 & 10 & 7 \\
\hline $92 / 93$ & 71 & 2010 & 2275 & 4959 & 8180 & 978 & 10 \\
\hline 93/94 & 100 & 646 & 1044 & 6009 & 1602 & 1664 & 0 \\
\hline 94/95 & 0 & 2564 & 7074 & 4200 & 4901 & 67 & 0 \\
\hline 95/96 & 106 & 879 & 3110 & 100 & 290 & 1004 & 150 \\
\hline 96/97 & 0 & 3232 & 4270 & 1017 & 4750 & 461 & 9 \\
\hline 97/98 & 180 & 7015 & 3550 & 5355 & 4570 & 314 & 0 \\
\hline 98/99 & 0 & 2140 & 4230 & 2514 & 3150 & 55 & 0 \\
\hline $99 / 00$ & 172 & 1350 & 8290 & 5040 & 2034 & 0 & 0 \\
\hline 00/01 & 0 & 860 & 2703 & 4230 & 4435 & 24 & 0 \\
\hline 01/02 & 0 & 3577 & 4579 & 514 & 3565 & 0 & 0 \\
\hline $02 / 03$ & 13 & 2824 & 2591 & 897 & 960 & 144 & 0 \\
\hline 03/04 & 0 & 3716 & 2276 & 3110 & 1317 & 225 & - \\
\hline $04 / 05$ & 26 & 3100 & 5375 & 4521 & 3038 & 2761 & - \\
\hline 05/06 & 2 & 820 & 3650 & 3450 & 2875 & 2225 & - \\
\hline 06/07 & 15 & 6750 & 3570 & 3020 & 2173 & 2 & - \\
\hline 07/08 & 12 & 5700 & 2700 & 5510 & 5600 & 2 & - \\
\hline 08/09 & 0 & 2200 & 680 & 5550 & 2450 & 108 & - \\
\hline $09 / 10$ & 271 & 1710 & 4490 & 1734 & 2307 & 3210 & - \\
\hline 10/11 & 31 & 5600 & 2050 & 369 & 990 & 2904 & - \\
\hline $11 / 12$ & 265 & 4250 & 4500 & 3901 & 957 & 1 & - \\
\hline $12 / 13$ & 0 & 1110 & - & 4275 & 3332 & 2980 & - \\
\hline $13 / 14$ & 0 & 203 & 5540 & - & - & - & - \\
\hline
\end{tabular}


Appendix 5. Number of Bean Geese recorded at mid-monthly counts in the census area Egeside, 1976/19772013/-. A bar (-) indicates that no complete count was carried out that month.

Antalet sädgäss inräknade vid mittmånads-inventeringar i räkningsområdet Egeside säsongerna 1976/19772013/-. Minustecken (-) anger att ingen komplett inventering genomfördes den månaden.

\begin{tabular}{|c|c|c|c|c|c|c|c|}
\hline & October & November & December & January & February & March & April \\
\hline $76 / 77$ & - & 23 & - & 177 & - & 574 & - \\
\hline $77 / 78$ & 22 & 23 & 1100 & 3100 & - & 1690 & 480 \\
\hline $78 / 79$ & 0 & - & - & 648 & 0 & 517 & - \\
\hline $79 / 80$ & 18 & 305 & 453 & 17 & 0 & 1390 & - \\
\hline $80 / 81$ & 0 & 29 & 263 & 1700 & 1100 & 412 & 691 \\
\hline $81 / 82$ & 67 & 104 & 0 & 0 & 0 & 8000 & 2000 \\
\hline $82 / 83$ & 16 & 3 & 1243 & 950 & 1046 & 3500 & 10 \\
\hline $83 / 84$ & 14 & 250 & 200 & 2780 & 1610 & 1850 & 1250 \\
\hline $84 / 85$ & 352 & 0 & 2409 & 0 & 0 & 1760 & 1585 \\
\hline $85 / 86$ & 0 & 21 & 740 & 0 & 121 & 2630 & 980 \\
\hline $86 / 87$ & 50 & 66 & 620 & 0 & 0 & 10 & 160 \\
\hline $87 / 88$ & 0 & 17 & 1017 & 2350 & 4924 & 6541 & 422 \\
\hline $88 / 89$ & 0 & 10 & 4244 & 3400 & 890 & 500 & 565 \\
\hline $89 / 90$ & 0 & 54 & 0 & 5090 & 3268 & 420 & 380 \\
\hline 90/91 & 0 & 780 & 3700 & 3420 & 516 & 698 & 165 \\
\hline 91/92 & 0 & 0 & 1210 & 5181 & 710 & 500 & 500 \\
\hline 92/93 & 0 & 41 & 2738 & 3700 & 2295 & 15 & 180 \\
\hline 93/94 & 0 & 23 & 1230 & 3696 & 2500 & 3000 & 375 \\
\hline 94/95 & 0 & 356 & 2175 & 3687 & 1829 & 270 & 100 \\
\hline 95/96 & 0 & 79 & 995 & 200 & 30 & 2660 & 0 \\
\hline 96/97 & 0 & 384 & 1450 & 0 & 1299 & 0 & 50 \\
\hline 97/98 & 0 & 500 & 700 & 1320 & 360 & 1050 & 0 \\
\hline 98/99 & 0 & 3 & 150 & 300 & 649 & 1400 & 0 \\
\hline $99 / 00$ & 8 & 0 & 220 & 2620 & 1019 & 70 & 1 \\
\hline $00 / 01$ & 0 & 9 & 240 & 2320 & 1160 & 500 & 0 \\
\hline $01 / 02$ & 25 & 1560 & 2800 & 877 & 4300 & 40 & 0 \\
\hline $02 / 03$ & 2 & 313 & 2840 & 1009 & 1065 & 31 & 0 \\
\hline 03/04 & 0 & 15 & 7990 & 732 & 573 & 0 & - \\
\hline $04 / 05$ & 0 & 257 & 1680 & 2738 & 1228 & 651 & - \\
\hline $05 / 06$ & 2 & 5 & 3686 & 40 & 370 & 116 & - \\
\hline 06/07 & 0 & 69 & 630 & 843 & 994 & 1 & - \\
\hline 07/08 & 0 & 806 & 937 & 2517 & 800 & 0 & - \\
\hline 08/09 & 0 & 0 & 950 & 1112 & 675 & 16 & - \\
\hline 09/10 & 0 & 33 & 638 & 210 & 170 & 1070 & - \\
\hline 10/11 & 30 & 158 & 180 & 0 & 470 & 1650 & - \\
\hline $11 / 12$ & 19 & 168 & 2901 & 2992 & 1951 & 0 & - \\
\hline $12 / 13$ & 0 & 1145 & - & 1198 & 1406 & 740 & - \\
\hline $13 / 14$ & 0 & 959 & 839 & - & - & - & - \\
\hline
\end{tabular}


Appendix 6. Number of Bean Geese recorded at mid-monthly counts in the census area Ivösjön, 2006/20072013/-. A bar (-) indicates that no complete count was carried out that month.

Antalet sädgäss inräknade vid mittmånads-inventeringar i räkningsområdet Ivösjön säsongerna 2006/20072013/-. Minustecken (-) anger att ingen komplett inventering genomfördes den månaden.

\begin{tabular}{rrrrrrrr}
\hline & October & November & December & January & February & March & April \\
\hline $06 / 07$ & - & - & 467 & - & 1165 & 12 & - \\
$07 / 08$ & 0 & 600 & 2000 & 1250 & 211 & 0 & - \\
$08 / 09$ & 0 & 0 & 10 & 725 & 1750 & 0 & - \\
$09 / 10$ & 0 & 0 & 110 & 260 & 16 & 35 & - \\
$10 / 11$ & 0 & 370 & 0 & 38 & 109 & 470 & - \\
$11 / 12$ & 10 & 300 & 620 & 425 & 366 & 0 & - \\
$12 / 13$ & 0 & 311 & - & 637 & 3 & 345 & - \\
$13 / 14$ & 4 & 560 & 127 & - & - & - & - \\
\hline
\end{tabular}

